\title{
أثر الإلزام بالإفصاح عن اسم شريك المراجعة فى تقرير مراقب الحسابات على قرار الاستثمار
}

على حسن على إبراهيم السمسار

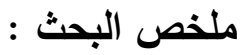

يستهدف البحث دراسة واختبار أثز الإلزام بالإفصاح عن اسم شريك المراجعـة فى تقرير مراقب الحسـابات وفقا للتعديلات الجديدة فى معايير المراجعـة الدوليـة، يناير 2015 ، على قرار الاستثمار ، من ضـوء واقع بيئة الممارسـة المهنيـة المصـرية ،

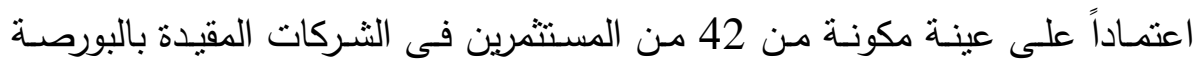
المصرية. ولإختبـار فرض البحث والاجابـة على تسـاؤلاته، تم الاعتمـاد على دراسـة نظريـة تجريبية، ومن خـلا الدراسـة النظريـة توصل الباحث إلى وجود تأثثر للإلكزام بالإفصاح عن شريك المراجعة على قرار أصحاب المصالح بصفة عامـة. ومن خلال

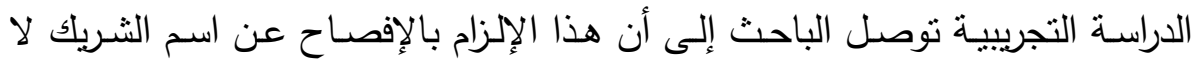

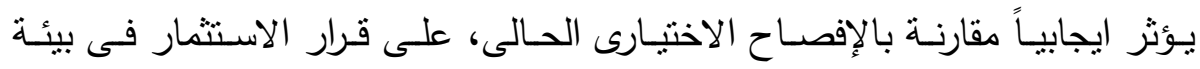
الممارسة المهنية المصرية وتم رفض فرض البحث الرئيسى. المصطلحات الرئيسية المستخدمة فى البحث : شريك المراجعة - قرار الاستثمار - الإلزام بالإفصاح عن شريك المراجعة 


\section{The effect of Mandatory Disclosure of Engagement Partner Name in the auditor report On Investment decision. An Experimental Study .}

\section{Abstract :}

The research aims to Study and examine the effect of adding audit partner name in auditor report(Mandatory Disclosure of the Engagement Partner Name) according to the new modified international auditing standard ISA 700 (revised) on Investment decision In the Egyptian professional practice environment. Depending on sample consist of 42 of the investors in listed companies in Egyptian Stock Exchange. The theoretical aspect of the research shows that, there is an effect for Mandatory Disclosure of the Engagement Partner Name on Stakeholders decisions. And Based on the experimental study the researcher has reached that, Mandatory Disclosure of the Engagement Partner Name doesn't has a positive Affects comparing with current Optional Disclosure on Investment decision In the Egyptian professional practice environment and results refused the research main hypotheses.

\section{Key Words :}

Mandatory Disclosure of the Engagement Partner Name Engagement Partner Name- investment decision. 


\section{1- مقدمـة:}

يسـتهدف مجلس معـايير المراجعـة والتوكيد المهنى الدولى(IAASB), التـابع للاتحــاد الـدولى للمحاسـبين(IFAC), القيـام بالمراجعـة المسـتمرة, والتحـديث الـدائُ, لتطـوير المعـايير الدوليـة للمراجعـة(ISAs), عندـ الضـرورة, للتماشـي مـع التغييـرات المتلاحقة التى تحدث فى بيئة الاعمال الحديثة(IAASB,2015)، وتلبيةً لاحتياجات مسـتخدمى تقارير المراجعـة والقوائم الماليـة, لتعزيـز الاتصـال بينهم وبين المراجـع،

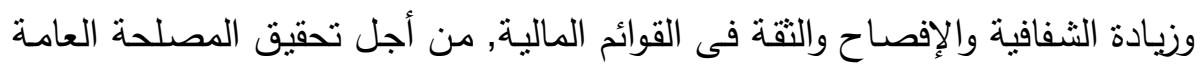
لجميع الاطراف المتعاملة.

وكان الاتجاه في تطوير معايير المراجعة الدولية نحو تقرير مراقب الحسابات

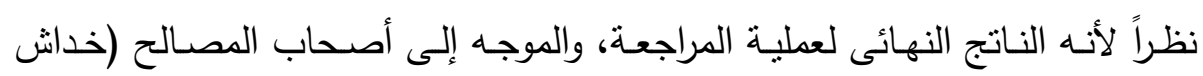

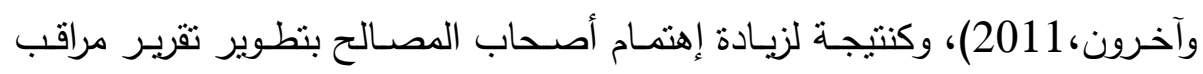

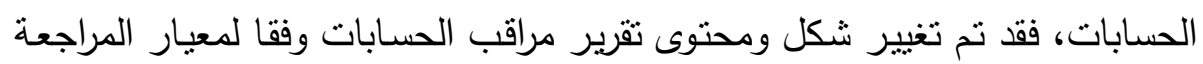
اللدولى ISA700 المعدل لسـنة 2015 ، مسن خـلال إضـافة فقرات جديدة وتعديل فقرات اخرى قائمة. فاستمرارية الثركة والإفصاح عن حالات عدم التأكد تمثنان إنذاراً مبكراً بالأمور المحتملة، والتى قد تؤدى إلى عدم قدرة الثركة على الاستمرار ، لذلك وجب الإفصاح عنها من قبل الادارة، وتقييم ذللك الإفصاح من قبل مراقب الحسابات

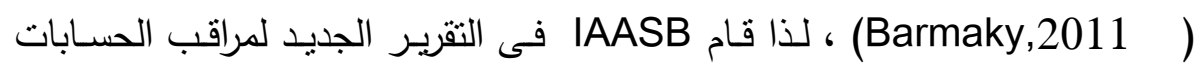

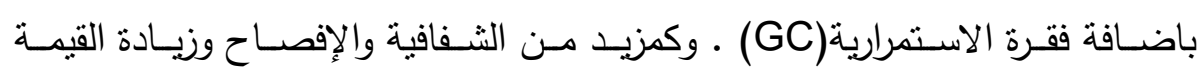

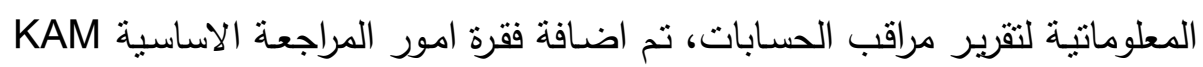

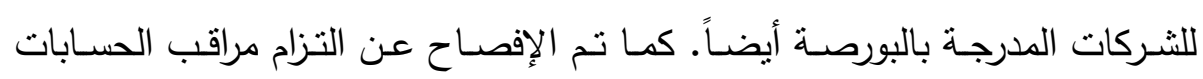
بأخلاقيات المهنة وكذلك القوانين واللوائح ذات الصلة، بالاضـافة إلى تقديم توضيح

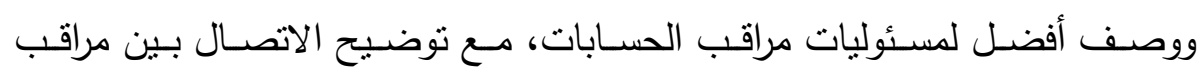

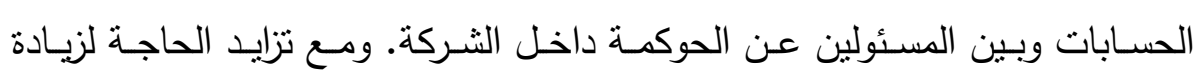

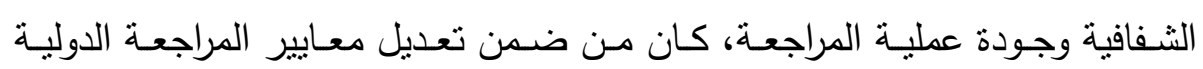


الخاصـة بتقرير مراقب الحسابات اضـافة فقرة اسم شريك المراجعة في تقرير مراقب الحسابات الجديد (Daniel,2014) ، وذلك اذا كان هناك شريك مراجعة.

والجدير بالذكر أن أى تغيير أو تطوير فى شكل ثقرير مراقب الحسابات يكون

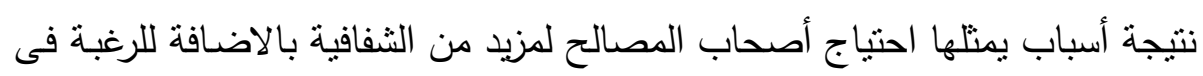

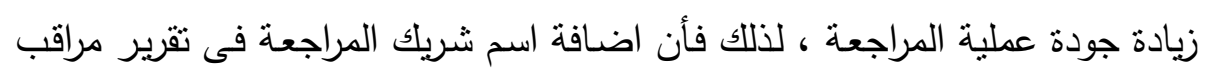

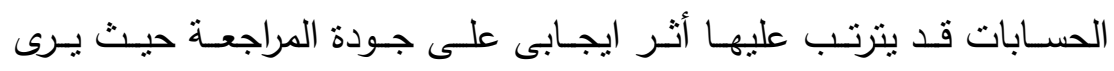

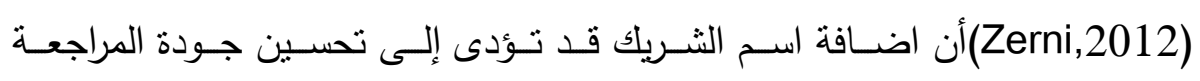
بطريقتين: الأولى أنها قد تزيد من إحساس المساءلة لثريك المراجعة والتى قد تقع

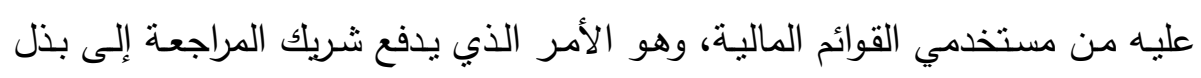

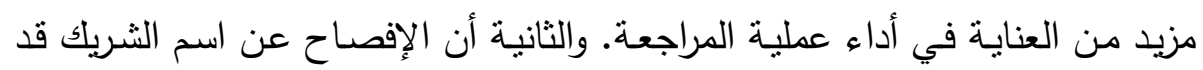

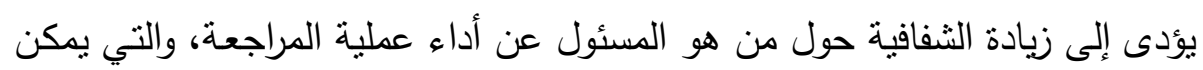

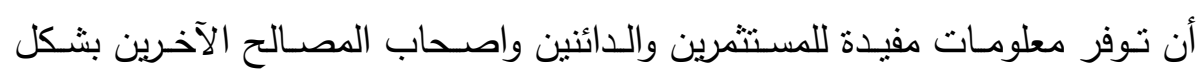

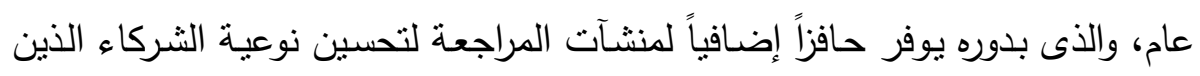
سيتم مشاركتهم. وقد أوضحت المادة 302 من قانون Sarbanes-Oxley تفسيراً

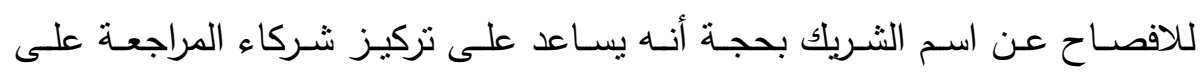
مسئولياتهم بشكل أفضل. وبرى (Kyungha,2015) أن الإفصـاح عن اسم شـريك تُكئك المراجعة له عدة مزايا تساعد مستخدمى تقرير مراقب الحسابات على معرفة معلومات

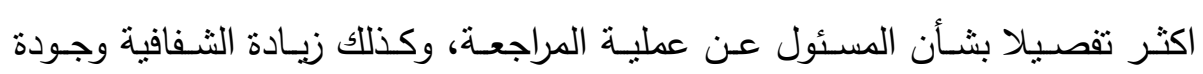

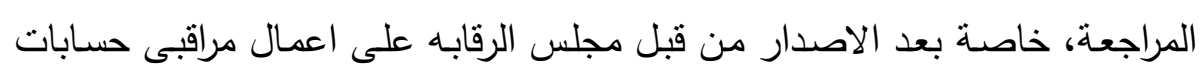
الثركات المقيده بالبورصه الامريكية (008-PCAOB 2015) ، والمعيار (

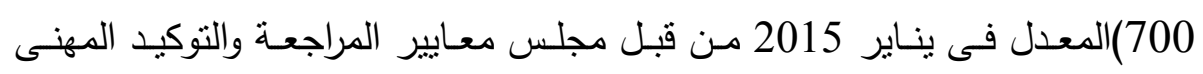


وعلى الجانب الاخر توجد عدة دراسات توضـح أن الإفصساح عن اسم الشريك المراجعة لا ينطوى بالضرورة منافع واضحة فى بعض الجوانب، لذلك قابل الإفصاح عن اسم الثريك عدة انتقادات، فتوصلت دراستى (Blay et al.,2014 ) و Davis (et al., 2012)

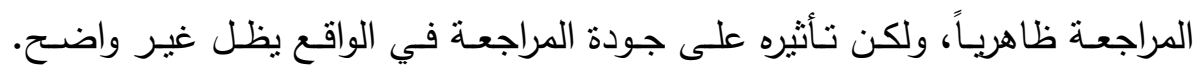

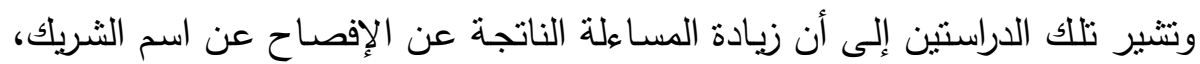
ستزيد جهود المراجعة ولكن ذلك لا يعتبر دليلاً صريحاً عن الزيادة المرتبطة بفعالية الإنية عمليـة المراجعة.

هذا وقد ذكرت دراسة (2015Jeffrey) أنه قد بظن بعض المتعاملين بالتقرير

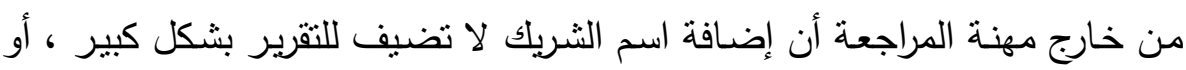
حتى تأثثر ملحوظ ، ولكنها فى الحقيقة إضـافة مهمـة ،خاصـة لأصـحاب المصـالح وبصـفة خاصـة المسـتثرين ، ففى اثتـاء اضطراب سـوق الأوراق الماليـة والفضـائح المالية فى الأونـة الاخيرة وتضرر المستثربن بأنخفاض سعر السهم ، وجب معرفة من هو المسؤول عن المعلومات المالية التي يزعم المستثمرون أنهم اعتمدوا عليها عند شراء الأسهر ومن هم الذين سيرفع دعوى عليهم لاسترداد الخسائر • ويؤيد ذلك الـ

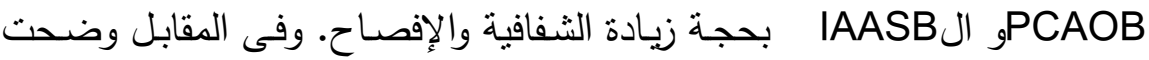
دراسة (2015Jeffrey) بعض الأنتقادات تجاه الإفصاح عن شريك المراجعة بما له له من أثر قد يعرض شريك المراجعة لمواجهة خطر التقاضـى او التسبب لله بضـرر مهنى . وفى ضـوء التطـورات فـى معـايير المراجعـة الدوليـة، وخاصــة معيـار التقريـر (الدولى الخاص بتقربر مراقب الحسابات والمعايير المتعلقة به، واضـافة اسم شريك المراجعة ، وبالاشـارة إلى الاختلافات السابقة عن أثز الإفصاح عن اسم

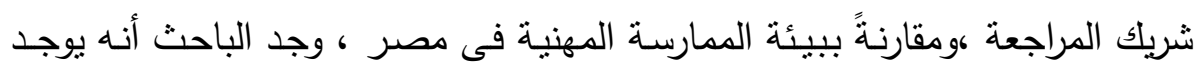

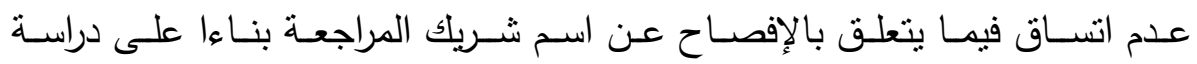


استكثافية قام بها لعينة من تقارير مراقبى الحسابات ـ حيث وجد الباحث أن أغلبية التقارير لم يفصح فيها عن اسم شريك المراجعة ولكن افصـح فيها عن اسم مراقب

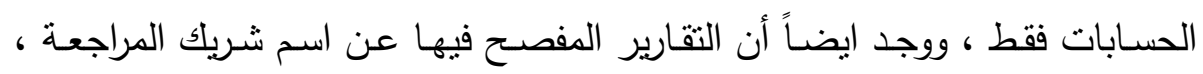
كان فيها الإفصاح شكلياً واختياريا دون وجود قانون أو معيار يلزم بالإفصاح عن اسم فئم شريك المراجعة .

ومن ناحية اخرى تحتوي القوائم المالية التي تتشرها الشركات على معلومات هامة ومفيدة لمستخدميها من بنوك ومستثمرين وجهات حكومية وغيرها .ونظرا لزيادة

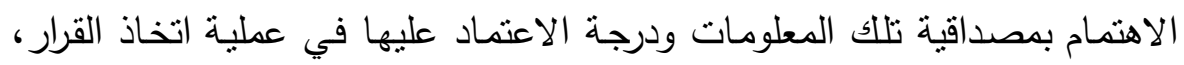
كان لا بد من وجود جهة محايدة ومستقلة تقوم بعملية التأكد من حقيقة وعدالة المعلومات الواردة في تلك القوائم المالية .و هذه الجهة غالبا ما تتمثل في مراقب

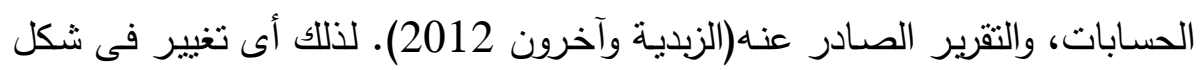
ومحتـوى ثقريـر مراقب الحسـابات قـد يـؤدى إلـى تغييـر فـى رأى متخذـى القـرار

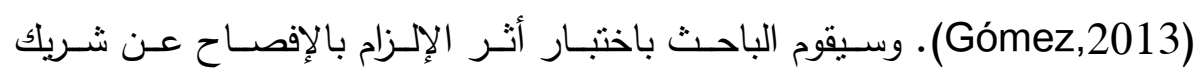

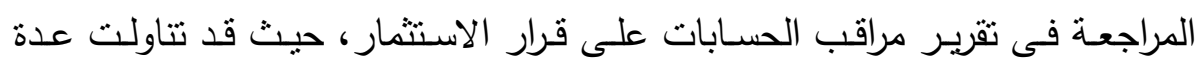
دراسات أسباب اضافة اسم شريك المراجعة فى ثقرير مراقب الحسابات وكذا أثر ذلك فرابك

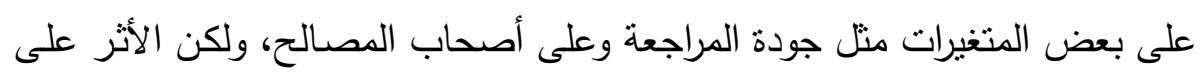

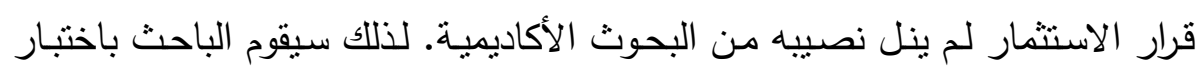
أثر الإلزام بإضافة اسم شريك المراجعة على قرار الاستثمار .

وخلاصة لما سبق نجد أن هناك العديد من الآراء بشأن قبول ورفض اضافة اسم الثريك فى تقرير مراقب الحسابات، وكذلك اختلافات فى تحديد الاثار المترتبة عن التن

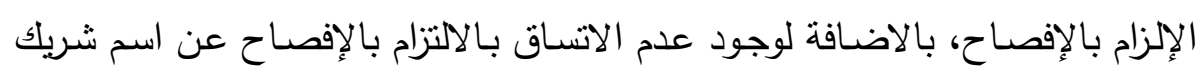

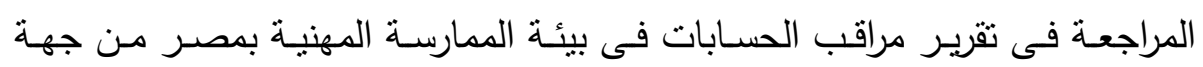
أخرى.لذا سيقوم الباحث بدراسـة أثر الإلزام بالإفصـاح عن اسم الثـريك على قرار 
الاستثمار ، وأن وجد هذا التأثير هل يمكن اقامة دليل تجريبى عليه، وهذا ما سيجيب عليه البحث نظرياً وتجريبياً.

\section{2- 2 مشـكلة البحث :}

قام الـIAASB بتطوير المعـايير المرتبطـة بتقرير مراقب الحسـابات فى يناير

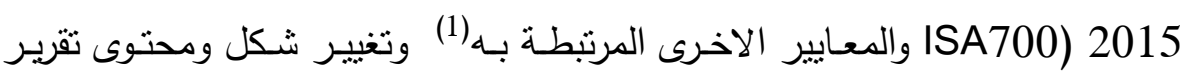

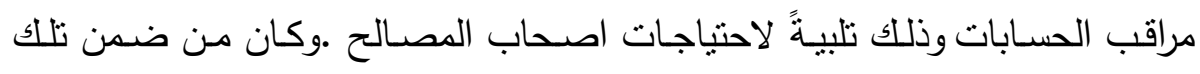

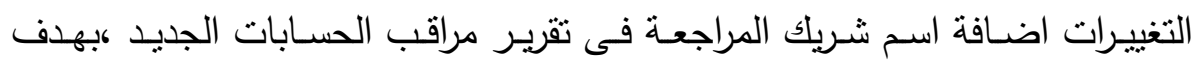
التوسع فى الإفصاح والثفافية فى تقرير مراقب الحسابات .وقد أدى ذلك التغيير إلى نى وجود عدة أنتقادات من قبل ممارسى مهنة المراجعة تجاه الإفصـاح عن اسم شريك فرك المراجعة نتيجة الضرر المهنى وخطر التقاضى الذى قد يقع على البعض فى حالة

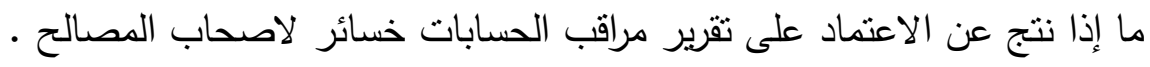
ويمكن صباغة مشكلة البحث فى صـورة التساؤلات التاليـة :-

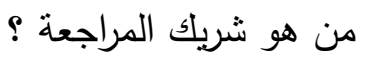
لماذا وجد طلب رسمى على الإفصاح عن اسم شريك المراجعة فى ثقرير مراقب

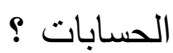

ISA700 , ISA 701 , ISA 705 , ) ISA700 المعايير الدولية المرتبطة بمعيار التقرير (ISA 706 ,ISA 720 ,ISA 570 وبالنظر إلى بيئة الممارسة المهنية المصرية نجد أنه لايوجد إلزام بالإفصاح عن اسم شريك المراجعة

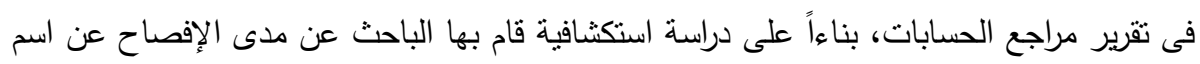

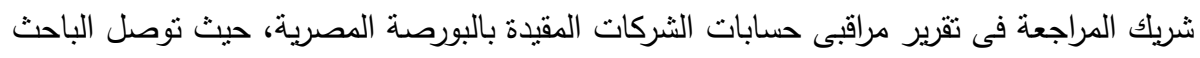
إلى أن اغليية التقارير لايفصح فيها عن اسم شريك المراجعة، وأن المفصحين عن اسم شريك الهيك

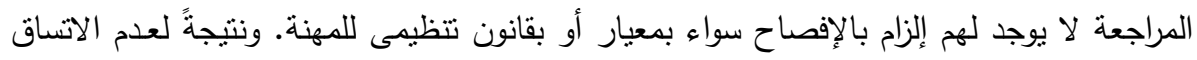

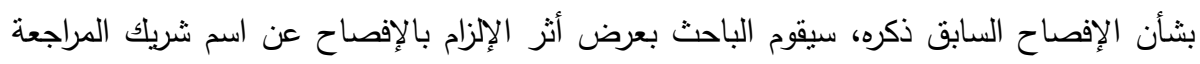
فى تقرير مراقب الحسابات وفقا لاخر التعديلات على فئة من اصحاب الصصالح وهم المستثمرون. 
هل يحتاج المستثمرون اضافة اسم شريك المراجعة فى تقرير مراقب الحسابات؟

وهل يؤثر ذلك على قرارهم ؟

3-

يهدف البحث لدراسـة أثر الإلزام بالإفصـاح عن اسم شريك المراجعـة فى تقرير

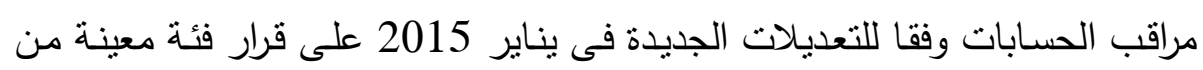

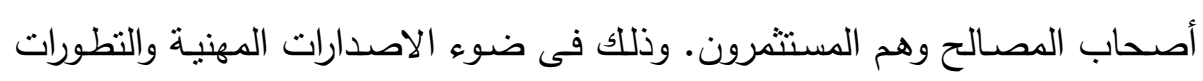

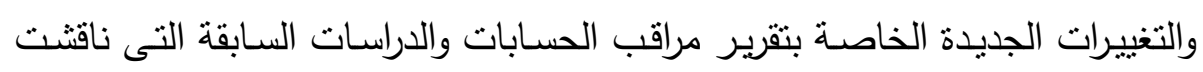
هذا الموضوع من جهة، وفى ضوء واقع بيئة الممارسـة المهنيـة المصرية من جهة اخرى اعتماداً على دراسة تجريبية.

4 - أهميـة ودوافع البحث فـى ضـوي نتـائج الدراسـة الاستكشـافية التـى قـام بها الباحث:

أجرى الباحث دراسة استكثافية على عينـة من تقارير مراقبى الحسابات لبعض الشركات المقيدة بالبورصة وبلغ عددهم 60 مفردة، وذللك بهدف معرفة مدى الإفصاح

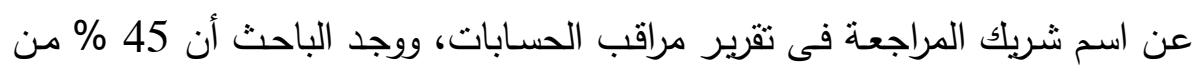
العينة تم الافصاح فيها فى تقرير المراجعة عن اسم شريك المراجعة وذلك من خلال مرلك

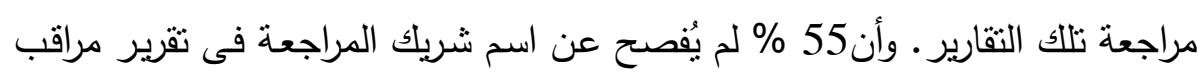

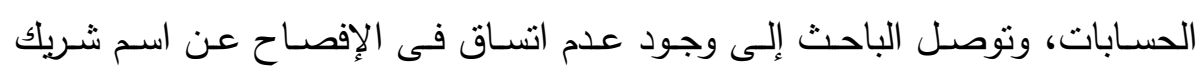
المراجعة فى بيئة الممارسة المهنية فى مصر (أنظر الملحق 2) ، وتزامناً مع تطور شكل وهيكل التقرير وإلزام معايير التقرير الدولية الثركات المقيدة بالبورصة بالإفصساح عن اسم الثربك فيجب دراسة الأثر الناتج عن ذلك التطور •

وتتمثل الاهمية الاكاديمية للبحث فى كونها بركز على بيأن أثر الإلزام بالإفصاح

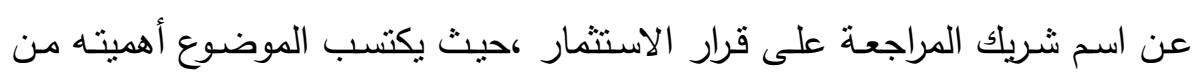

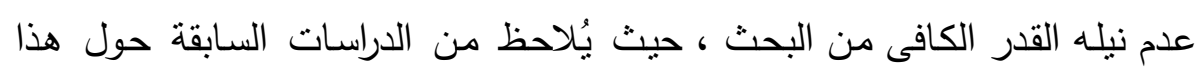


الموضوع أنها قد بدأت منذ عام , 2008 ، واختصت بدراسـة أثر الإفصساح سواء

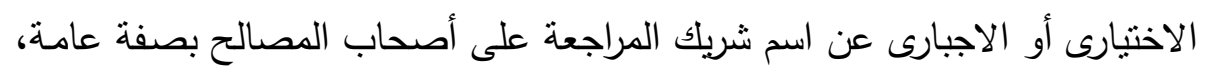
ولا توجد دراسات اخرى اختصت بالأثز على قرار الاستثمار فيما يخص الإلزام بالإفصاح عن اسم الثريك فى بيئة الممارسة المهنية المصرية وذلك فى حدود معرفة الباحث، مع العلم أنه توجد دراسات سابقة اخرى اختصت بدوران شريك المراجعة قبل عام 2008. وحسب اطلاع الباحث، فقد خلت البيئة المصرية من دراسات مماتلة استخدمت الأسلوب التجريبي، ولذلك فأن أهم وما بميز هذه الدراسة أنها طبقت في بيئة مختلفة عن تلك التي طبقت فيها الدراسات السابقة .

وتتبع الاهمية العملية للبحث بالنسبة للمستثمرين لكونه سيصل إلى نتائج يمكنها أن تؤثز على مصداقية تقرير مراقب الحسابات وبالتالى مصداقية القوائم، والتى من أنسين شأنها أن تساعدهم على ترشيد قرارهم.

وكنتيجـة لنـدرة الدراسـات التى تتاولت العلاقـة بـين الإفصـاح عـن اسـم شـريك

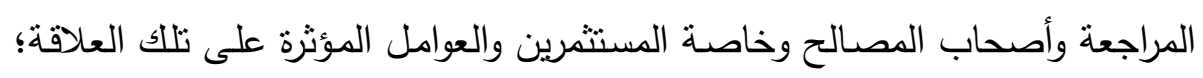

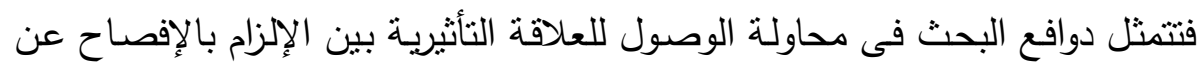
اسم الثريك وقرار الاستثمار • وايجاد دليل على وجود العلاقة محل البحث فى بيئة

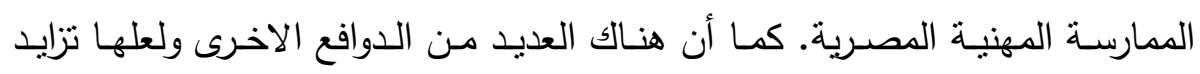
الطلب من قبل اصحاب المصالح على مزيد من الثفافية والإفصاح. وكذلك مسايرة النطوير فى تقرير مراقب الحسابات.

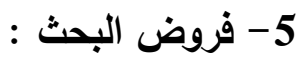

سوف يتم اشتقاق فرض البحث التالي نظرياً تمهيداً لاختباره تجريبياً :

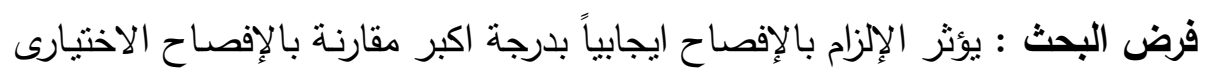

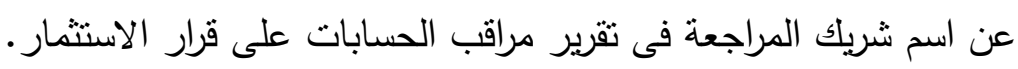




\section{6- حـدود البحث :}

يقتصر هذا البحث على دراسـة واختبار العلاقة بين الإلزام بالإفصـاح عن اسم

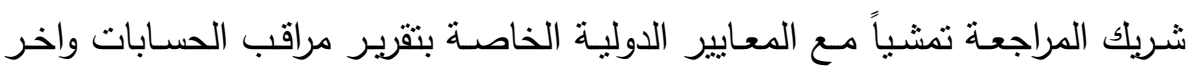

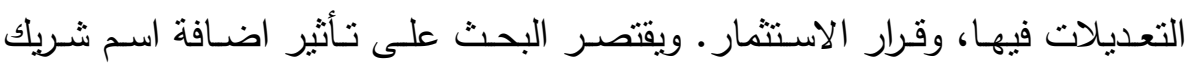
المراجعة فقط بنقرير مراقب الحسـابات دون غيره من التعديلات الاخرى في هيكل

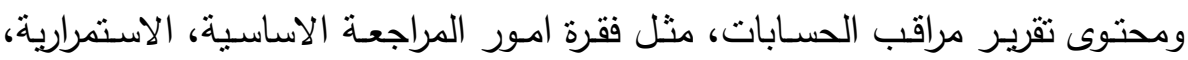

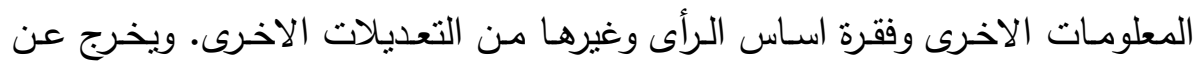
نطاق البحث المتغيرات الرقابية الاخرى التى قد تؤئز على العلاقة الاساسية محل

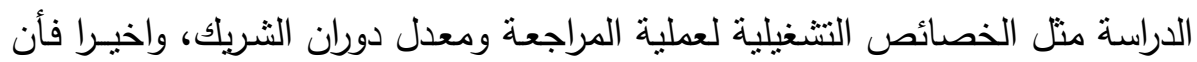
قابلية نتائج البحث للتعميم مشروطة بضوابط اختيار عينته.

\section{7- خطة البحث :}

لتحقيق أهداف البحث ومعالجة مشكلته، وفى ضوء حدوده، سوف يستكمل البحث

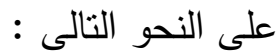

أولاً - الإفصاح عن اسم شريك المراجعة من منظور مهنى .

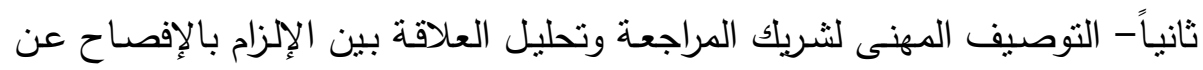
اسم شريك المراجعة وقرار الاستثمار واشتقاق فرض البحث. ثالثاً - الدراسة التجريبية واختبار فرض البحث. رابعاً - نتائج البحث والاجابة على تشاؤلاته . خامساً - التوصيات ومجالات البحث المقترحة .

\section{أولاً - الإفصاح عن اسم شريك المراجعة من منظور مهنى :}

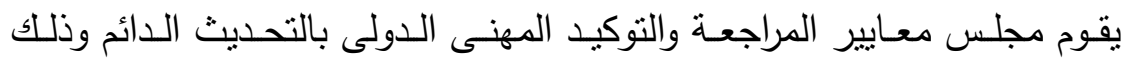

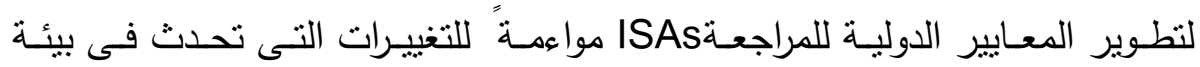
الاعمال الحديثة، وكذلك تلبية لاحتباجات مستخدمى تقارير المراجعة وزيادة الشفافية

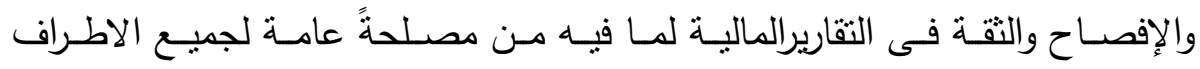


(IAASB,2015) ( وشـملت التحديثات في ينـاير 2015 تطوير المعـايير الخاصـة بتقرير مراقب الحسابات وتعديل شكل ومحتوى التقرير ، وكان من ضمن التعديلات فى التقرير اضافة اسم شريك المراجعة والتى جاءت تلبيةً للاحتياج لمزيد من الثفافية والإفصاح فى التقرير • وبدأ الامر فى العقد الماضى حيث كان الإلزام بنص القانون حيث ألزمت العديد من الدول (استراليا ، تايوان ، الصـين ) بالاضـافة إلى الاتحساد الأوروبى بتوقيع شريك المراجعة على تقربر مراقب الحسابات(Gold et al.,2012)

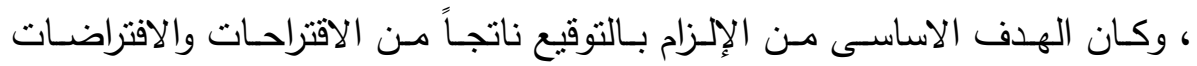

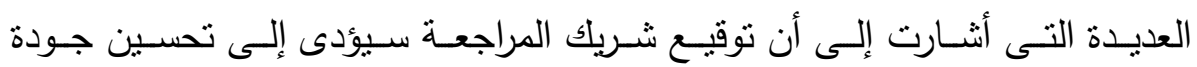

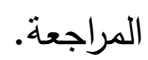
وكـان مبـرر تلـك الافتراضـات أن الإفصـاح عـن اســ شـريك المراجعـة سـيزيد

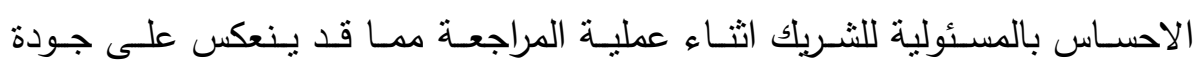

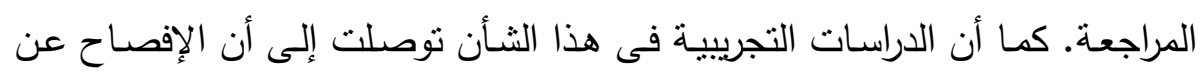

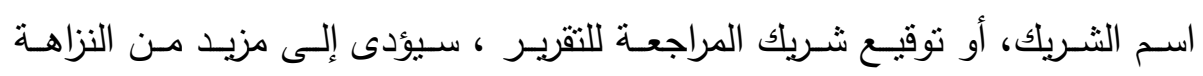

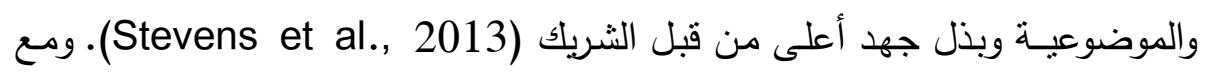

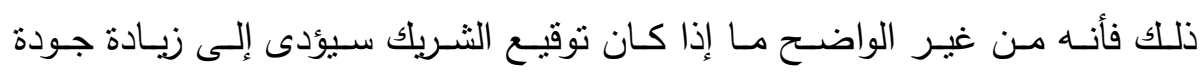

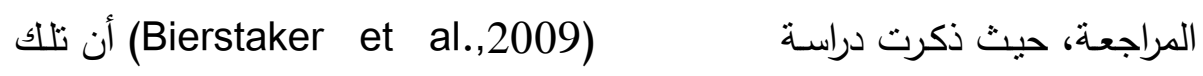
الافتراضات بشأن جودة المراجعة تعتمد على افتراض رفع مستوى المسئولية القانونية على شريك المراجعة .

وبـدأ الامـر بـالظهور بواقـع توقيـع شـريك المراجعـة لتقريـر مراقب الحسـابات

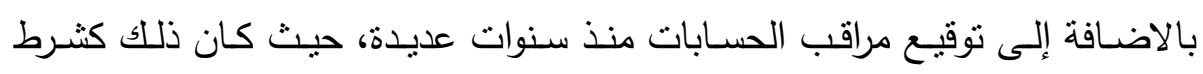
قانوني، وذلك وفقا لقانون الثركات الأسترالية لعام 2001، القسم 324 (10) ومن هنا كانت بداية الإلزام بتوقيع الثريك (Fargher et al., 2008). بالإضافة إلى ونى

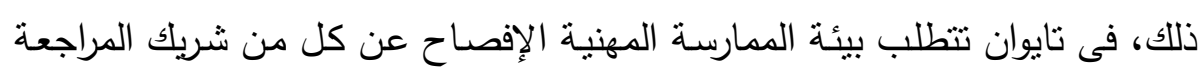
وكذا شريك الفحص فى تقرير مراقب الحسابات (Chen et al., 2008) ـ اما فى في كن الاتحاد الأوروبي فكان التوجه الجديد إلى تحديد عدة منطلبات جديدة لتقرير مراقب 
الحسـابات، بمـا يضــن توضـيح الالتخزام بمعـايير المراجعـة الدوليـة الصـادرة مـن الـ IAASB

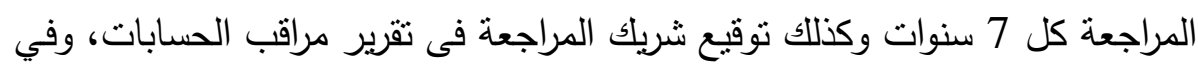
الآونـة الأخيرة نفذت المملكة المتحدة هذا الثـرط كجزء مـن قـانون الثـركات لعـام

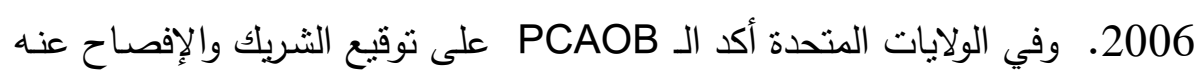
فى تقرير مراقب الحسـابات ايضـاً ، لذلك يشير الاتجاه الدولى إلى اهمية الإفصـاح عن اسم شريك المراجعة .

وأنثارت دراسة (Blay et al., 2014) ايضاً أن الآثار الناتجة عن عملية اعتماد

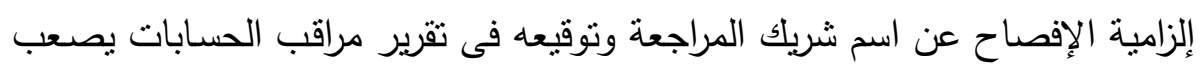

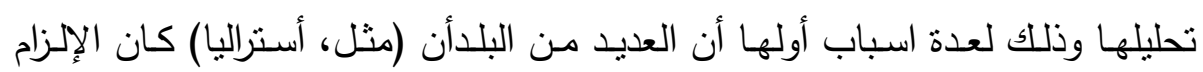
بالإفصـاح عن شـريك المراجعة عرفاً وكان بمثابـة سياسـة إلزامية، وذلك قبل الإلزام بمعيار مراجعة دولي. وثانيها أن عدة دول اعتمدت توقيع شـريك المراجعـة إلزاميا

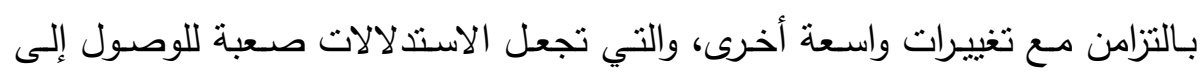
الاثار الصافية لذلك التغير (على سبيل المثال، اعتماد الدول لمعايير التقارير المالية

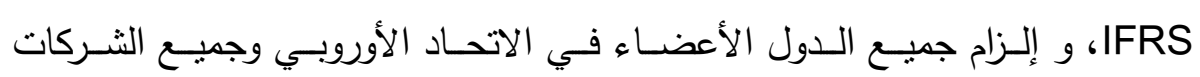
بالـIFRS ، وفي نفس الوقت الإلزام بالإفصاح عن اسم شريك المراجعة في تقرير مراقب الحسابات ) بالإضافة إلى وجود مجموعات اعتمدت الإلزام بالإفصاح مبكراً

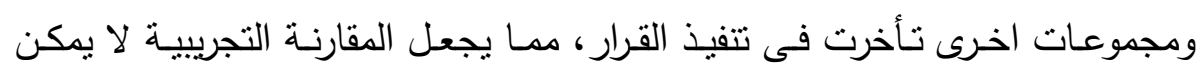
الاعتماد عليها.

ومن ناحيـة المؤسسـات المهنيـة والاصـدارات الخاصـة بالموضـوع، فالـ PCAOB كان الأبرز حيث أصدر القواعد المقترحة المتعلقة بتعزيز الثفافية في تقرير مراقب باتبه

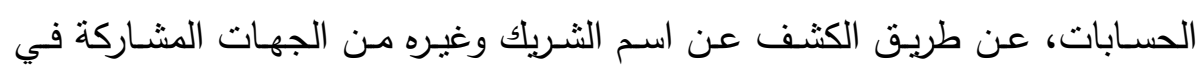
عملية المراجعة. كما فتح الباب للتعليقات على القواعد التى اصدرها. وكانت ابرز

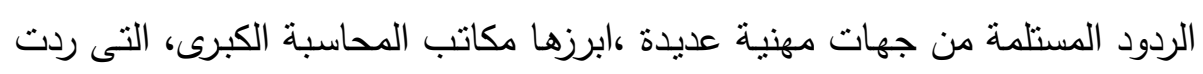


بأن اسم شريك المراجعة لن يضيف جديداً، ولا علاقة له بجوده المراجعة، ولكن على الى الـ

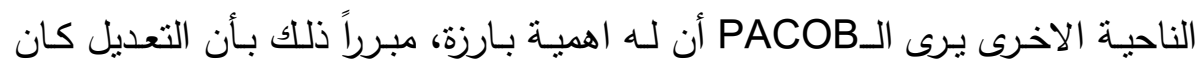

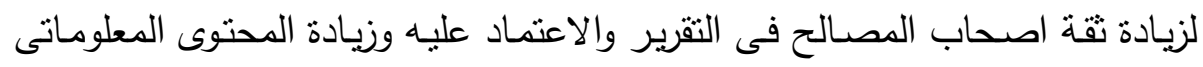
بـالتقرير • وكان ابرز الإصـدارات الخاصـة بهذا الثـأن هـى الاصدارات رقم 009-

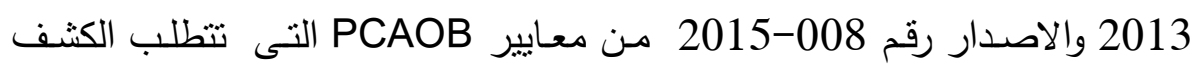
عن اسم الشـركاء فى المراجعة (وغيرها من منشـآت المحاسبة و كذلك الأشخاص الذين شاركوا في عملية المراجعة من غير المحاسبين) في تقرير مراقب الحسابات .

ومن ناحية|الIAASB ، فأن التعديلات فى التقرير الجديد لمراقب الحسابات ظهرت

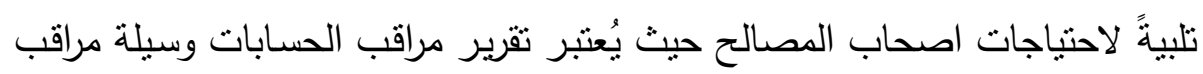

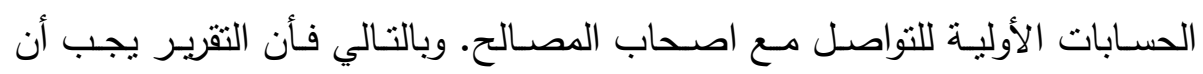
يعمل على توفير قيمة لهم، ولا سيما المؤسسات الاستثمارية والمحللين الماليين، لأنهم يربدون معرفة المزيد عن عملية المراجعة والحصول على مزيد من الإيضـاحات بشأن

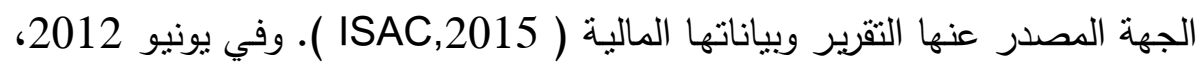
أصدر IAASB دعوة للتعليق (ITC) على تحسين تقرير مراقب الحسابات للحصول على ردود الفعل على اتجـاه IAASB المقترح لتقريـر مراقب الحسـابات المستقبلي. وفي يوليو 2013، أصدر مسودة خاصـة بالتقرير الجديد " المعايير المقترحة الجديدة الخاصـة بـالإبلاغ عـن البيانـات الماليـة التى تم مراجعتهـا، والتـي شـملت المعـايير

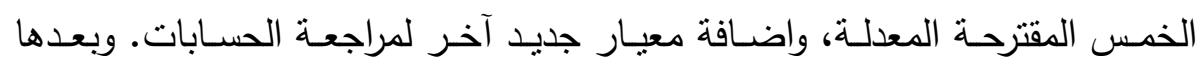
أصسر IAASB معسيير تقريـر مراقب الحسـابات الجديدة والمعدلـة في يناير عـام

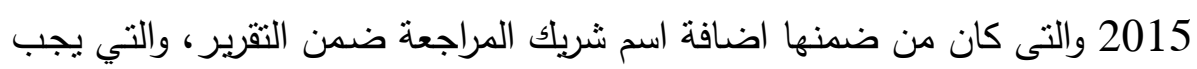
تطبيقها في عمليات مراجعة القوائم المالية للفترات المنتهية في أو بعد 15 ديسمبر .2016

و على مستوى مكاتب المراجعة الكبرى الاربعة، كان رد مكتب ديلويت سريعاً مرسلاً فى بريد إلكتروني موجه لا PACOB تعليقاً على الإشارة إلى اقتراح نوقيع 
اسم الثريك في الولايات المتحدة ، "نحن لا نعتقد أن هذا الثرط لـه أي صلة وثيقة

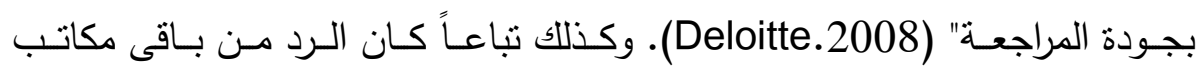

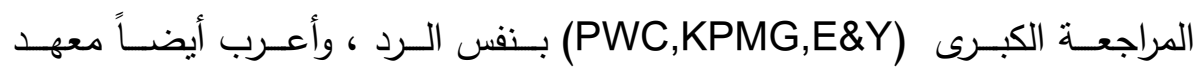
المحاسبين القانونيين في أنكلترا وويلز عن اعتراض على التعديل المقترح، وأنه ليس

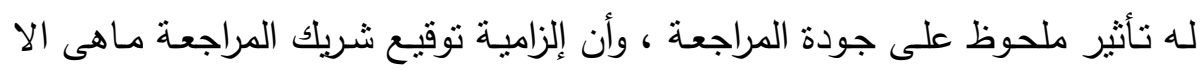

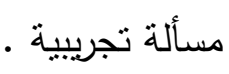

اما بالنسبة للواقع المهنى فى مصر فلقد تم تشكيل اللجنة الدائمة لمعايير المحاسبة والمراجعة وقواعد السلوك المهني المرتبطة بهما، بالقرارين رقم (498) لسنة 1997

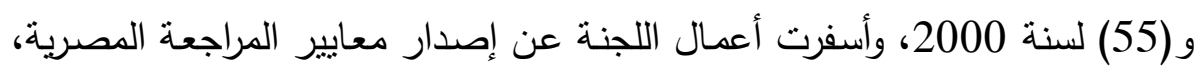

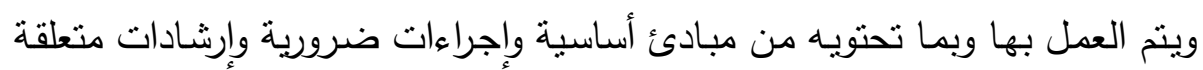

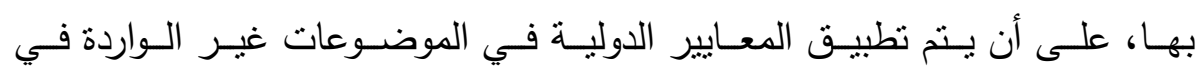
المعايير المصرية لحين صدور معايير مصرية لتلك الموضوعات، وبلغ عدد المعايير

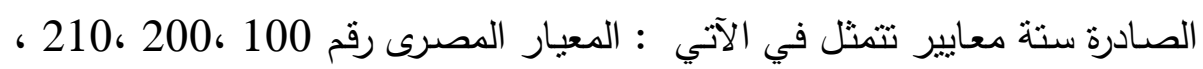

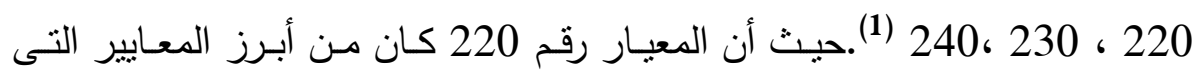
تتاولت شريك المراجعة، وذكرت بعض الوظائف التى يجب على الثريك القيام بها، سواء فى قبول المهام واستمرار العلاقات مع العملاء وبعض مهام المراجعة المحددة

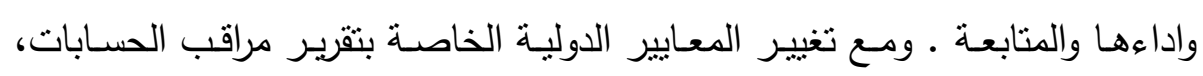

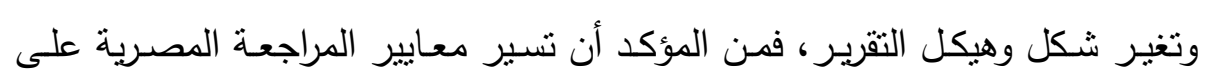
خطى المعايير الدولية مواءمةً للتغير والاتساق مع المعايير الدولية.

(1) المعيار المصري رقم (100) والخاص بإطار العمل لمعايير المراجعة المصرية،(200) والخاص براص

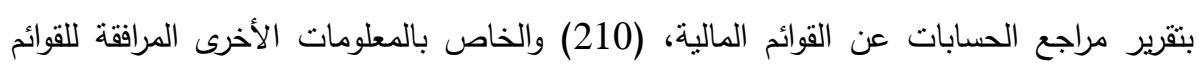

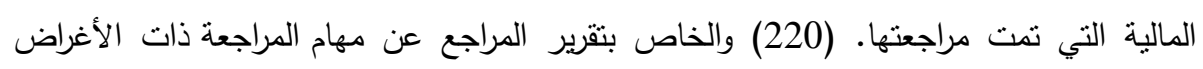

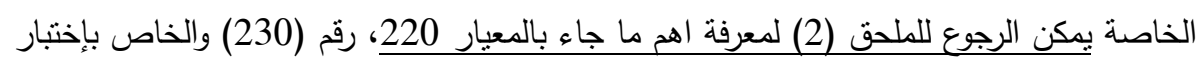
المعلومات المالية المستقبلية.، رقم (240) والخاص بمهام الفحص المحدود للقوائم المالية. 
ويخلص الباحث ممـا سبق إلى أن الاصدارات المهنيـة الامريكية والدولية تتفق

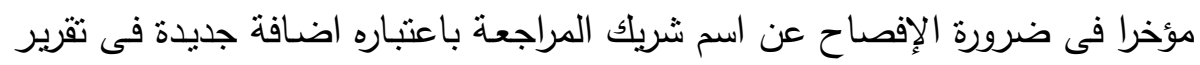

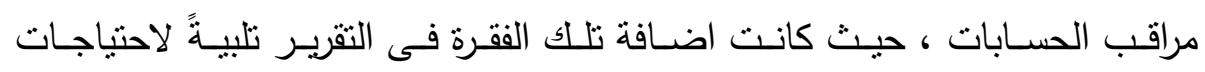

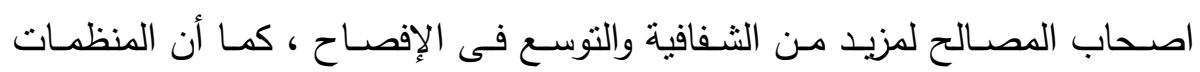
المهنيـة اشـارت إلى أن الإلزام بالإفصاح له عدة منافع حيث يمكن أن يؤدى لزيادة

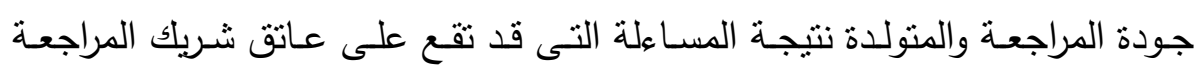
نتيجة تحمله مسئولية التقرير ، بالاضافة إلى مزيد من الثفافية والإفصاح المعلوماتى فى التقرير والتى قدُ يرشد قرارات أصحاب المصالح مثل المستثمرين ، وكذلك توفير

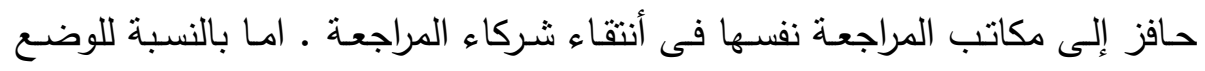
المهنى فى مصر ، فأنه يوجد عدم اتساق فى الإفصاح عن شريك المراجعة فى تقرير

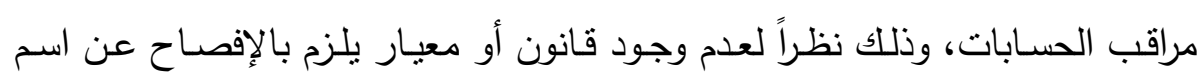
الثريك فى تقرير مراقب الحسابات. 
ويمكن تلخيص الدوافع واسباب الطلب على الإفصساح عن اسم شريك المراجعة فى تقرير مراقب الحسابات فى الإطار المقترح التالي:

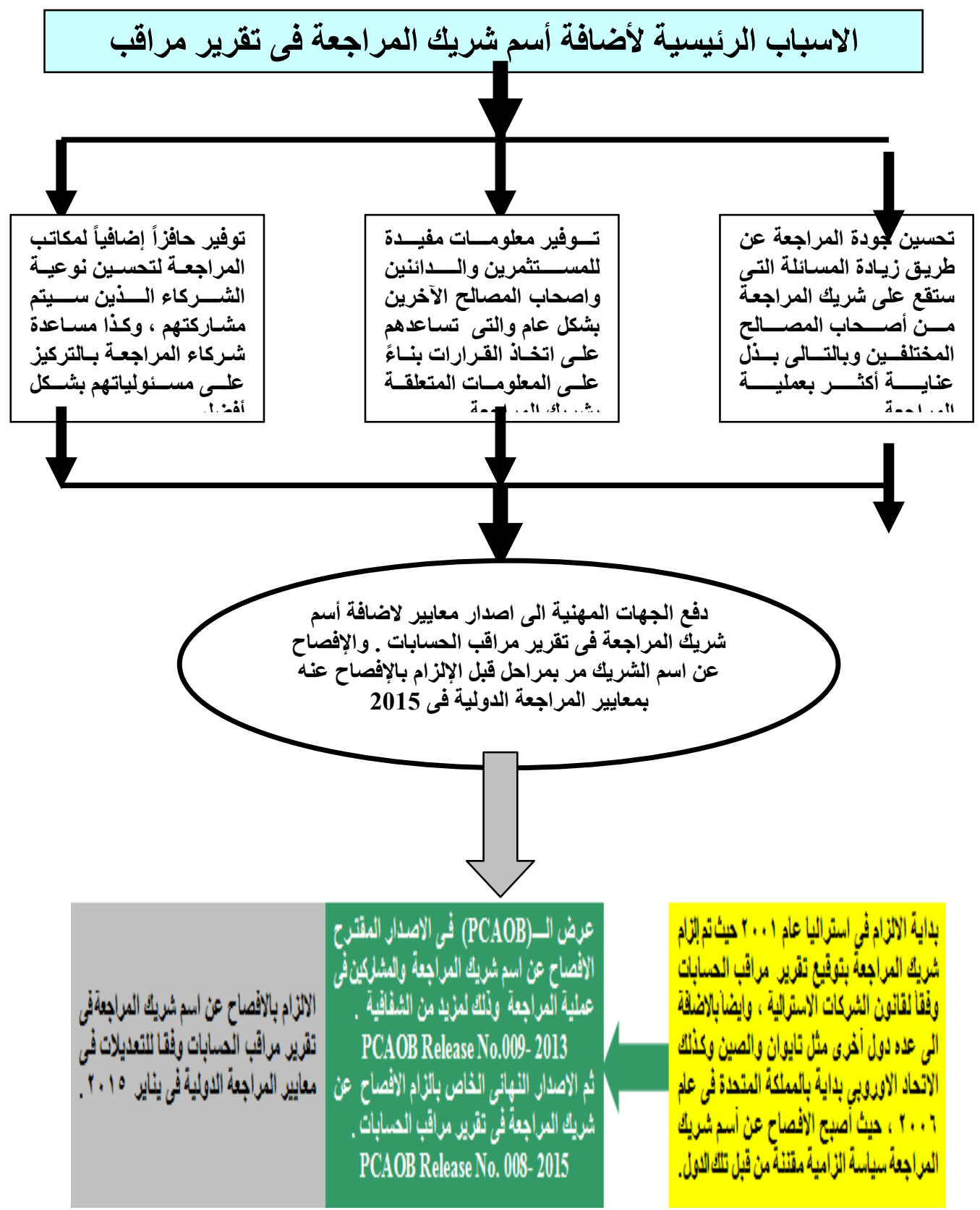


ثأنياً- التوصيف المهنى لشريك المراجعة وتحليل العلاقة بين الإلزام بالإفصاح عن اسم شريك المراجعة وقرار الاستثمار واشتثقاق فرض البحث.

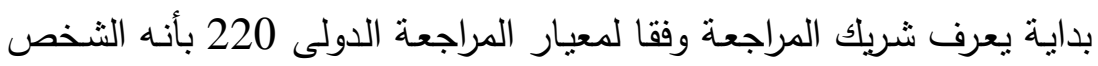
الموجود فى مكتب المراجعة المسئول بشكل مباشر عن الاشراف والرقابة على عملية المراجعة وفقاً للتكليف، وكذلك مسئول عن اصدار تقرير المراجعة ويجب أن يملك الك

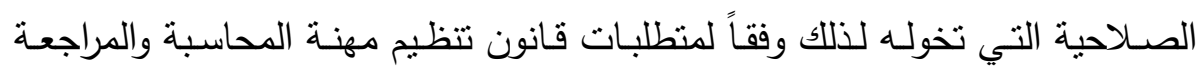
كما يمكن معرفة مهام شريك المراجعة والتى نص عليها المعيار 220 (ISA220)

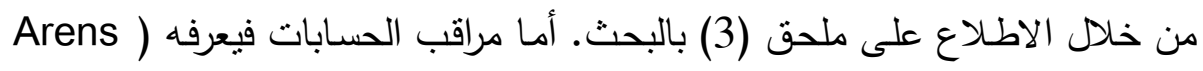

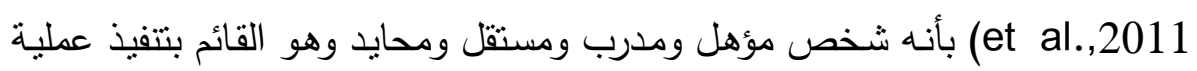

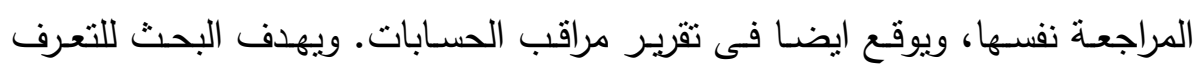
على اسباب اضافة اسم الثريك فى المراجعة فى تقربر مراقب الحسابات والإفصاح عنه، وأثز ذلك الإفصاح على قرار الاستثمار .

وفى ضـوء تحليل الدراسـات السـابقة والتـى اختصـت بدراسـة المتغيرين نجد دراسـة

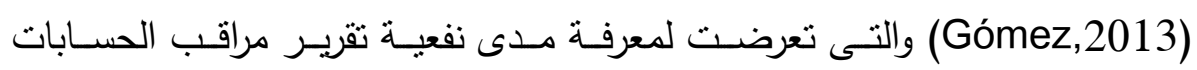

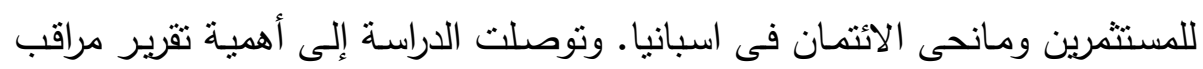

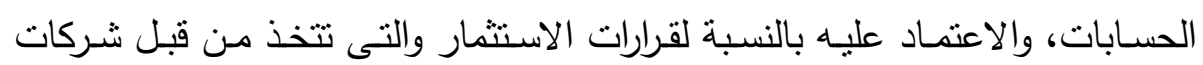
السمسرة والمتعاملين. كما توصلت الدراسة إلى أن كل المستثمرين ومانحى الائتمان

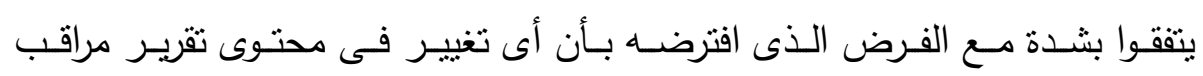

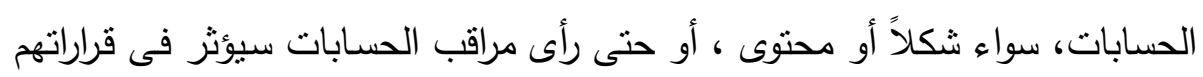

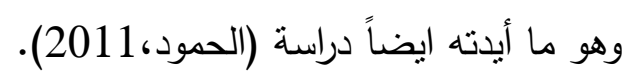

وهناك دراسة(Boolaky,2016) والتى اختصت بالإجابة عن مدى تأثير المعلومات المتوفرة في تقرير مراقب الحسـابات وتعديل التقرير على تصـورات مديري البنوك.

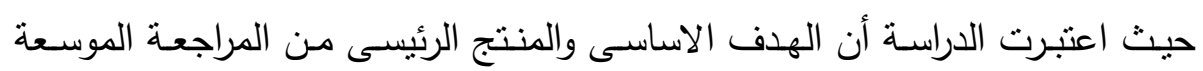

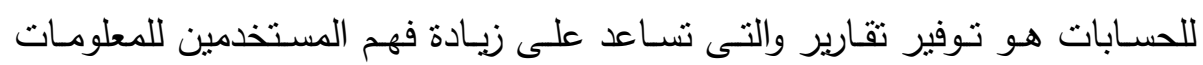


المالية و اضفاء مصداقية أكبر للتقارير المالية من خلال التحقق من التأكيدات التي

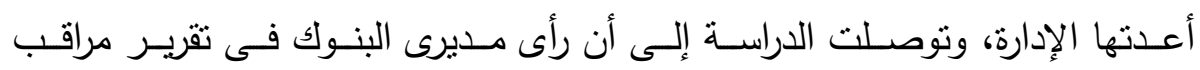

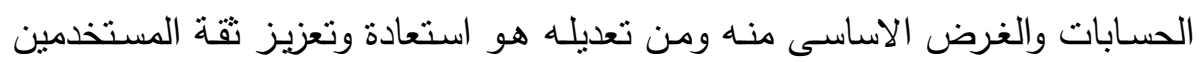

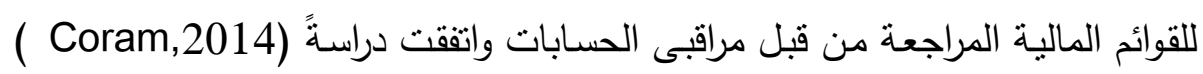
على نلك النتائج ايضاً .

واعتمدت دراسة (Boolaky,2016) على عدة مؤشرات لمعرفة أثر تعديل تقرير مراقب الحسابات على مديرى البنوك، فبالنسبة لزيادة الثقة فى القوائم المالية توصلت

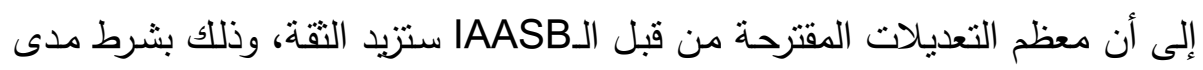

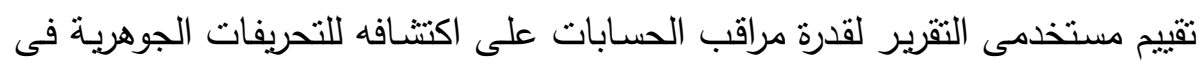

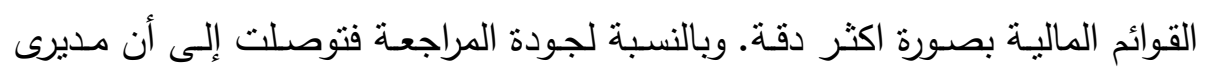

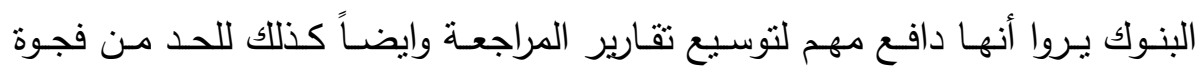
المعلومـات ولكن يجب تحديد الأثر على جودة المراجعة بدقـة. امـا بالنسبة للقيمـة المعلوماتية لنقرير مراقب الحسابات فيرى مديرو البنوك أن التعديلات المقترحة ستوفر

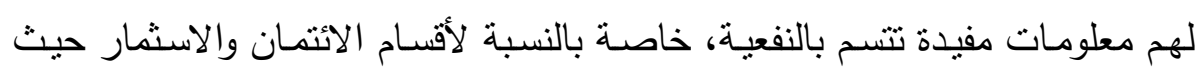
تعكس درجة معقولية القوائم المالية.

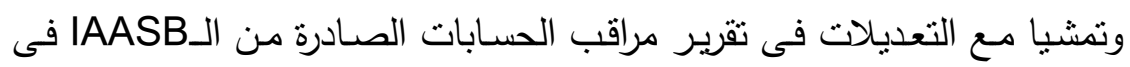

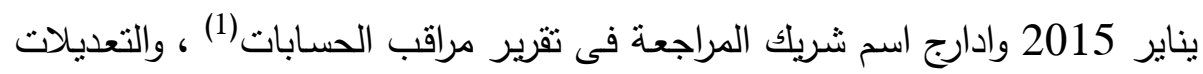

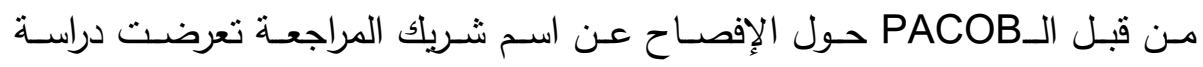
(Lambert et al.,2015)

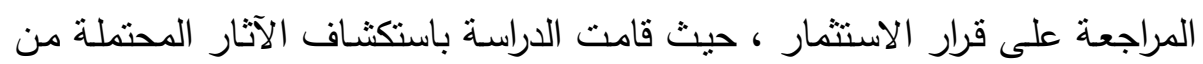

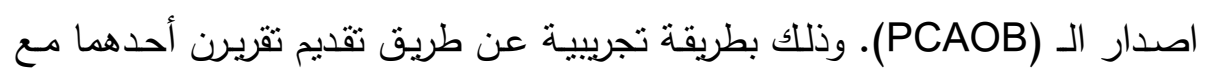

(1) بالنسبة لتقرير مراقب الحسابات المعدل وفقاً للتعديلات من قبل IAASB فى يناير 2015 مقارنة بالتقرير القديم أنظر ملحق 4. 
وجـود شـريك للمراجعـة والاخـر بـدون ذكـر اســ شـريك المراجعـة. وكـذلك تقسـيم

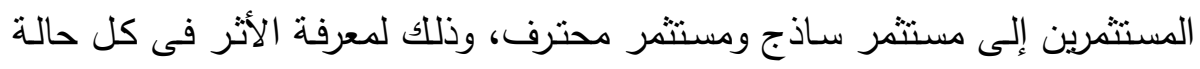
من الحالات. ووجدت الدراسـة أن المستثمر السـاذج قد لا يؤثر معرفـة اسم الثـريك على قرارهم بعد التجربـة. فى حين أن وجدت أن للافصـاح عن اسم الثـربك تأثنير على على قرار المستثمرين المحترفين خاصة المستثمرين الذين لديهم مزيد من الخبرة ومعرفة جيدة بالتقارير المالية.

وتعتبر معظم الدراسات السابقة مؤيدة للافصاح عن اسم شريك المراجعة وذلك من

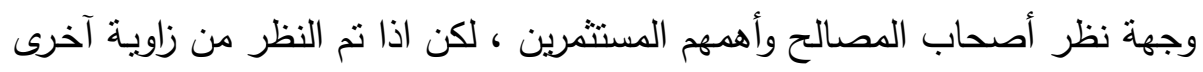

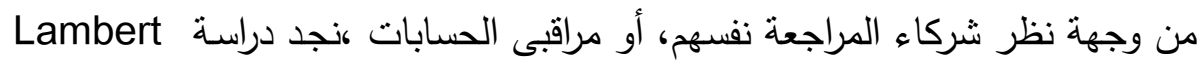

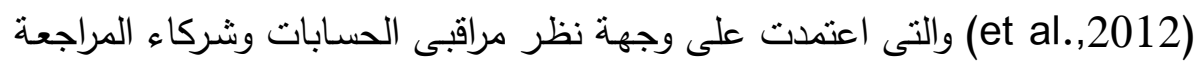
حيث توصلت إلى أن الإفصاح عن اسم الثريك قد يكون له عدة آثار غير مستحبة اعنداء ،والتى تؤدى إلى عواقب لن تعود بالنفع على شريك المراجعة ، حيث كان التأثير

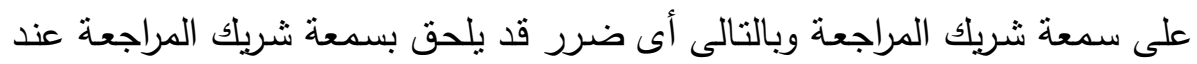
التعامل مع العملاء قد يؤدى ذلك إلى المساس بالحوافز التى يحصل عليها الثريك ، وبالتالى قد يؤدى ذلك تباعاً إلى أنخفاض مستوى استقلال شريك المراجعة .

ومن منظور آخر ، وعلى مستوى أصحاب المصالح بصفة عامة والتغييرات التى

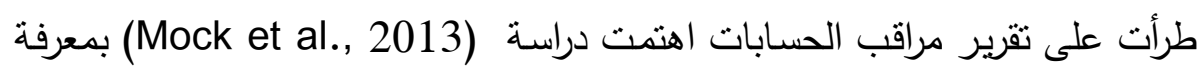

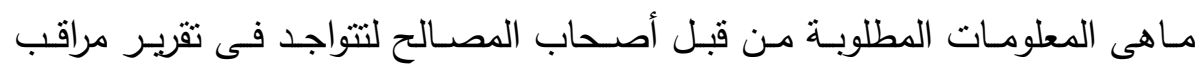

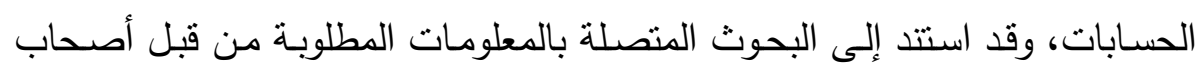

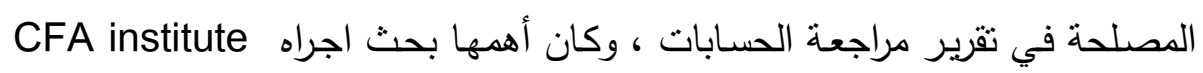

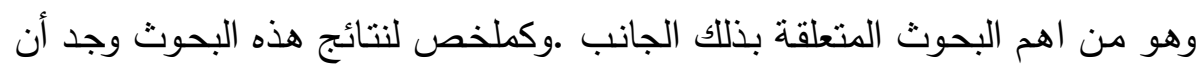

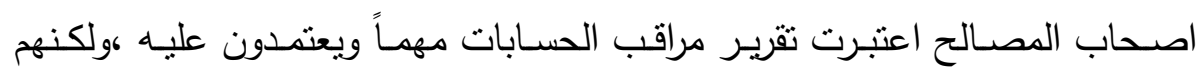
يرغبون فى مزيد من المعلومـات حول مراقب الحسـابات نفسـه والإفصـاح عن اسـ 
شريك المراجعة، وكذلك بيانات اضافية حول عملية المراجعة ، وكذا معرفة السياسات المحاسبية والمعلومات المتعلقة بالمخاطر .

وفيمـا تعلق بالإفصـاح عن اسم الثـريك فـى المراجعة وأثنره على جودة المراجعة

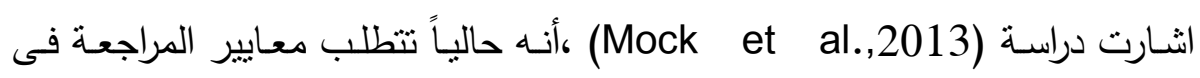
الولايـات المتحدة توقيع اسم شـريك المراجعة على تقرير مراقب الحسـابات ، وكذللك ايضاً العديد من الدول خارج الولايات المتحدة ـ ولعل الخلاف الرائج فى هذا الصدد فئرد بشأن الإفصاح عن اسم الشربك والخاص بما اذ سيؤدى توقيع شريك المراجعة لتقربر

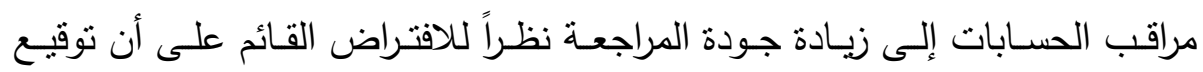

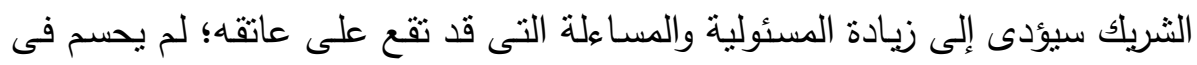
الدراسات الاخرى. ولكن يرى (Mock et al.,2013) أن الإفصاح عن اسم شريك لفيك

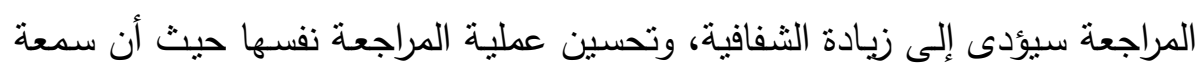

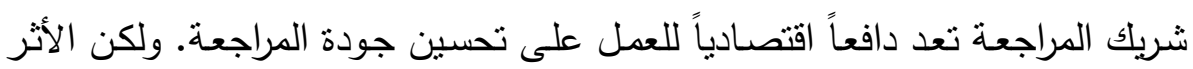

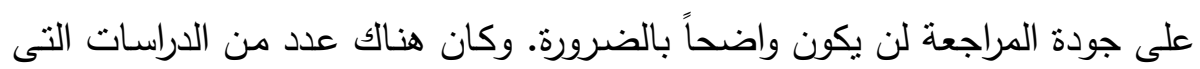

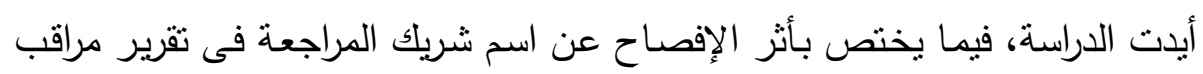

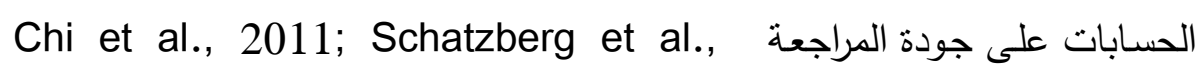
(2005; Blay et al.,2012) - حيث لم تتفق النتائج وكانت مختلطة، وبالتالى فأن الأثر على جودة المراجعة غير واضـح ومحدد. بالاضـافة أيضـاً إلى دراسـة (Davis et al., 2012)

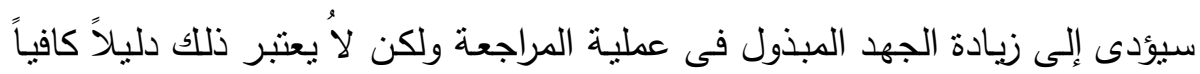
على زيادة جودة عملية المراجعة نفسها.

وعلى مستوى توقعـات اصـاب المصـالح مـن الإفصـاح عن شـريك المراجعـة فىى في

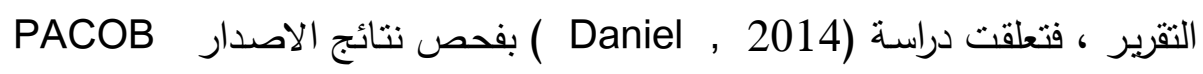
2013-009 وذلك لمعرفـة وجهة نظر مجموعـة مـن اصـحاب المصـالح فيى هذا

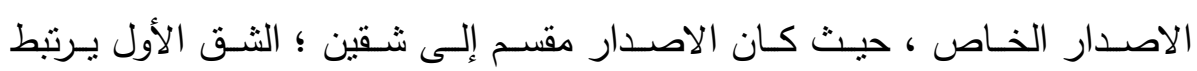


بالإفصاح عن اسم شريك المراجعة ، والثنق الثانى يرتبط بالإفصاح عن المشاركين فى عملية المراجعة وتحديدهم. حيث قام PACOB فى هذا الاصدار بعرض إلزام مراقبى الحسابات فى تقريرهم بالإفصاح عن اسم الثريك فى المراجعة وكذلك مكتب المراجعة، والمقر الرئيسى لذلك المكتب، وكذا نسبة سـاعات العمل التى تمت الثـاء المراجعة من قبل مشاركين آخرين (منت المراجع الداخلى للشركات محل المراجعة، أو ونئ

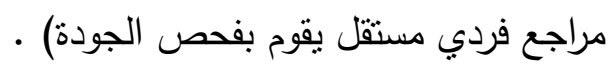

وتوصلت دراسـة(Daniel,2014) إلـى أن إلـام توقيع شـريك المراجعـة للتقريـر،

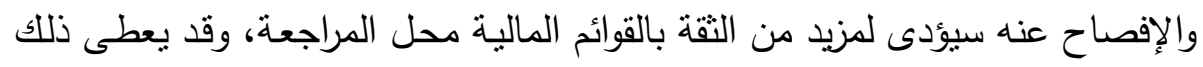

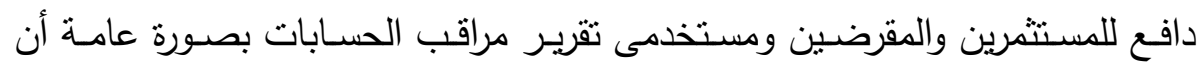
يعتمدوا بصورة أكثر على التقرير ، نظرا للمسئولية والمساءلة التى قد تقع على مراقب مربن

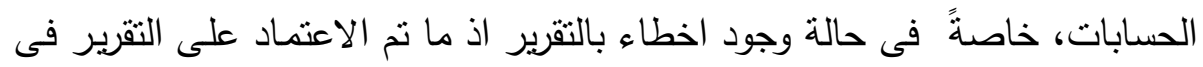

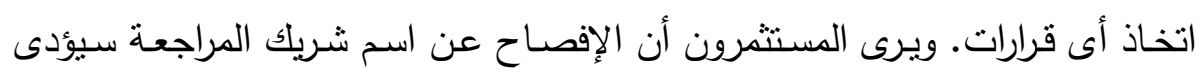
إلى اتخاذ قرارات استتمارية أفضل نظرا للشفافية الزائدة فى تقرير مراقب الحسابات، إنى كما سيوضح لهم الاخطار المحتملة، نظراً للأعتماد على تقرير مراقب حسابات يذكر

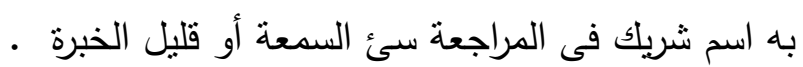
وعلقت دراسـة (Simnett, 2014) على التعديلات المقترحسة فى تقرير مراقب الحسابات من قبل الـ IAASB بشكل تفصيلى ؛ وفى الجزء الخاص بالإفصاح عن

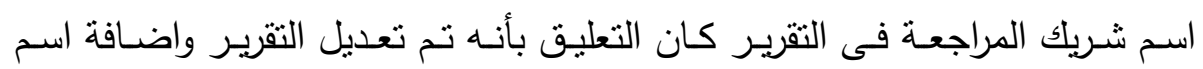

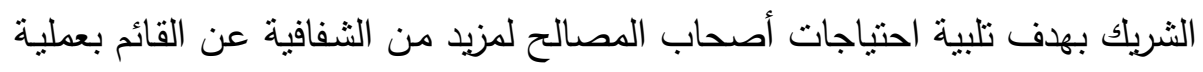
المراجعة ـ وكذلك زيادة حس المساءلة الثخصية عند شريك المراجعة، ولكن الاثار المحتملة، التى قد تتتج عن هذا التعديل، قد نؤدى إلى أخطار شخصية على الثريك

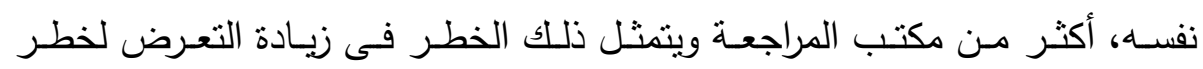

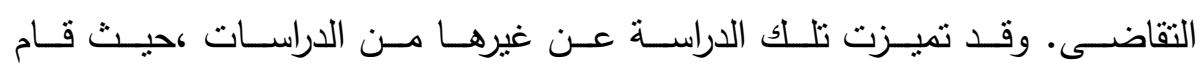
(Simnett,2014) المقترحة الخاصة بتقربر مراقب الحسابات وتحليلها تفصيلا لكل جزء وفقرة من فقرات 
التقرير المعدل المقترح ، حيث كان عدد الردود 165 موجـه إلى الـ IAASB والمرسل من مجموعة منتوعة من أصحاب المصالح (25 مكتب مراجعة ، 19 من 4عدى القوائم المالية فى الشركات ،13 من مستخدمى تقربر مراقب الحسـابات

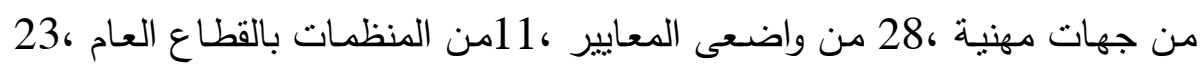

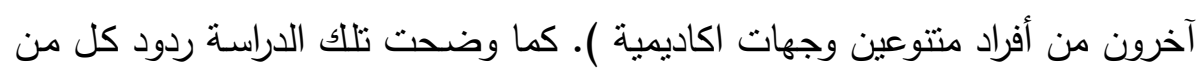

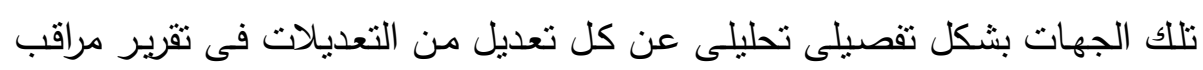

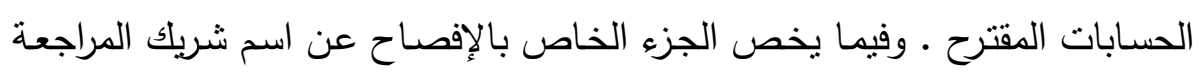
ففتم السؤال عن الرأى فى مـا اذا تم الإلزام بالإفصساح عن اسم الثـربك فى التقربر

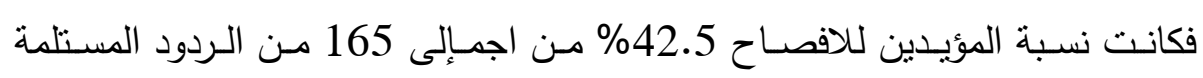

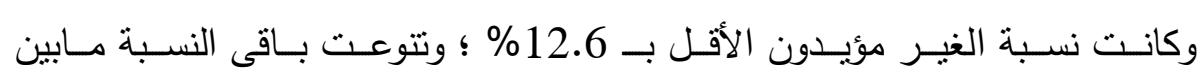
مؤيدين(بتعديل) أو غير مؤيدين(بتعديل).

وفيما يخص ثقرير مراقب الحسابات نفسه، سواء المعدل أو غير المعدل، وأهميته

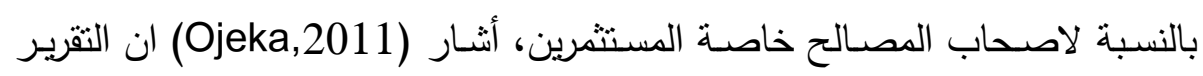

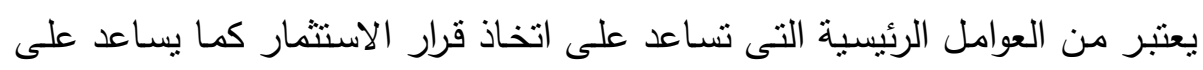

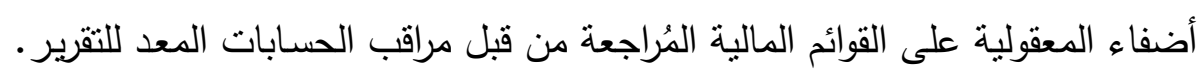
حيث يرى (Ittonen, 2012) أن مراقبى الحسابات يقومسون بييع الثقة والمعقوليـة

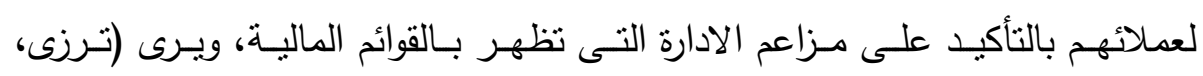
2013) انه اذ ما نم الاعتماد على تقرير مراقب حسابات بثأن معلومات وقوائم مالية

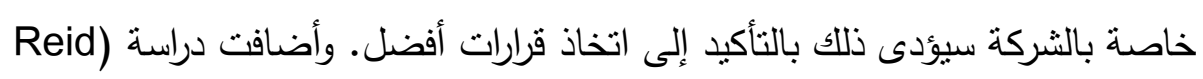
(et al., 2015 سيؤدى إلى تأثر القرار الاستثمارى. ويخلص الباحث مما سبق إلى أنه وفقا للنغييرات فى شكل ومحتوى تقرير مراقب

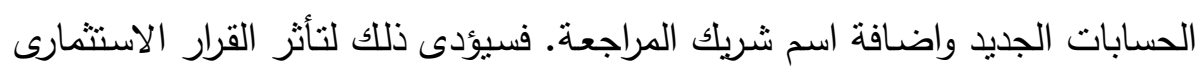
وهو مايفترضه الباحث، حيث توضح الدراسات السابقة مدى اعتماد المستثرون على تُرئ 
تقرير مراقب الحسابات، وأن أى تعديل في التقرير سيؤثر على القرار الاستثمارى. أما بالنسبة لاصحاب المصالح بصفة عامة فاشارت الدراسات السابقة على أن الإفصاح

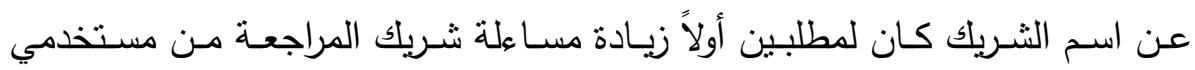
البيانات المالية، الأمر الذي قد يؤدي إلى ممارسة مزيد من العناية في أداء عملية

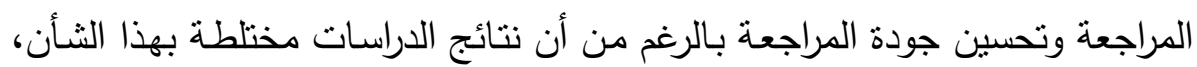

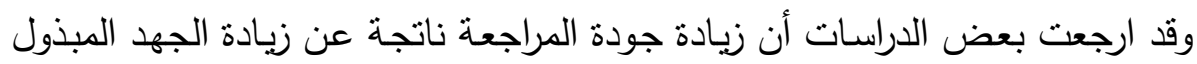
فى عملية المراجعة بسبب الاحساس بالمساءلة. ثانيا زيادة الثفافية عن المسؤول عن

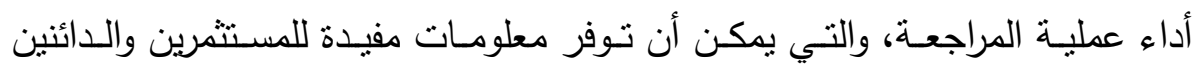

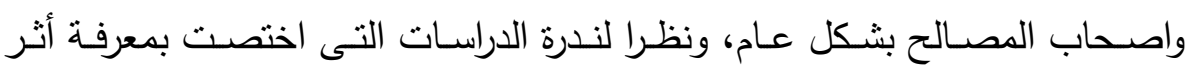
اضـافة اسم الثـريك بـالتقرير على قرار الاستثمار واقتصـرت على بعض المتغيرات

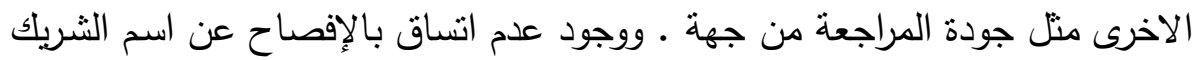

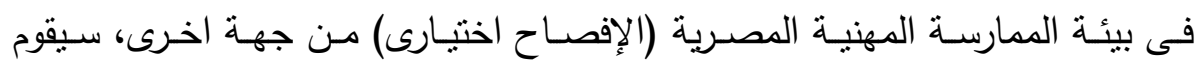
الباحث باختبار أثر الإلزام بالإفصاح عن اسم الثريك على قرار الاستثمار.

وبناءا على ما سبق يمكن اشتقاق فرض البحث كما يلى:

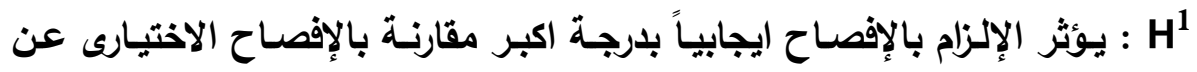
اسم شريك المراجعة فى تقرير مراقب الحسابات على قرار الاستثمار. ثالثاً - الدراسة التجريبية وإختبار فرض البحث . فى ضوء أهداف البحث وحدوده ومشكلته ولاختبار الفرض يأخذ نموذج البحث

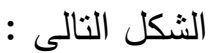




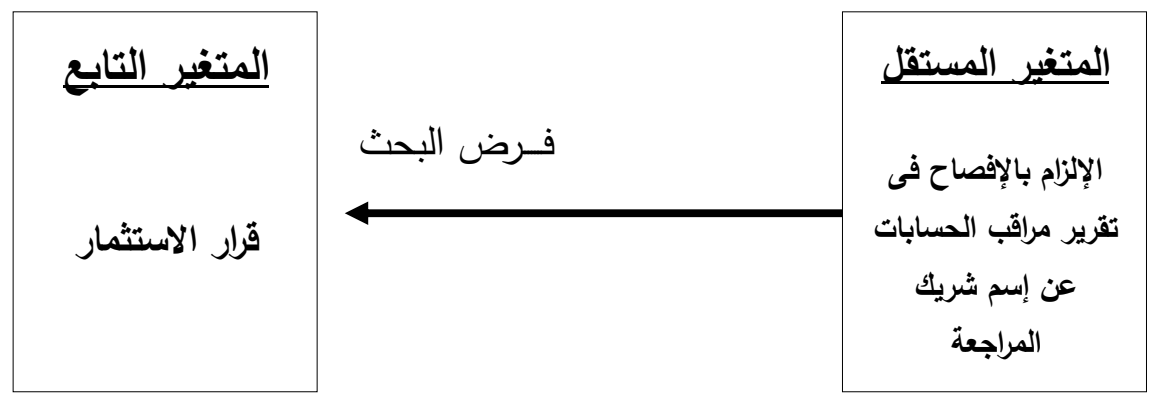

ولتحقيق أهداف البحث ومعالجة مشكلته تجريبياً، يتتاول الباحث منهجيته كما يلى:

1 - الهرف من الدراسة التجريبية :

تشتهدف الدراسة التجريبية اختبار أثر الإلزام بالإفصاح عن اسم شريك المراجعة فى : في تقريـر مراقب الحسـابات وفقا لمعيـار (ISA 700) لسـنة 2015 ومعايير التقرير المرتبطة به، على قرار الاستثمار . 2- مجتـمع وعينة الدراسة :

يتكـون مجتمـع الدراسـة مـن المسـتمرين بالاسـهم فـى بيئة الممارســة المهنيـة

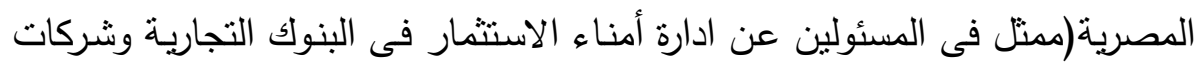

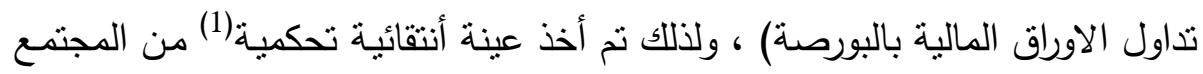

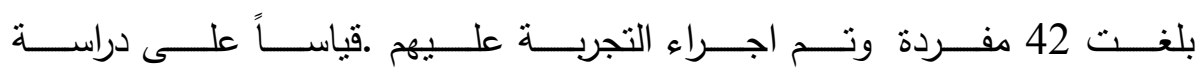

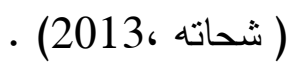

\section{3- أدوات واجراءات الدراسة :}

تعتمد هذه الدراسة التجريبية على حالات افتراضية، على خطى العديد من الدراسات

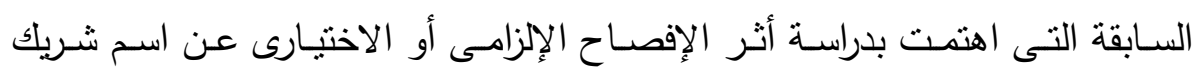

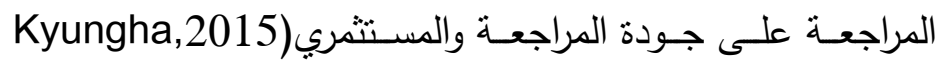

(1) العينة الحكمية روعى فى اختيارها عدة اعتبارات أهمها: المؤهلات العلمية والثهادات المهنية الحاصلين عليها. 
(willam et al.,2015 Veena\&Jodi,2016 ; Davis et al., 2012; تصميم قائمسة تختص بالدراسـة التجريبية تتضمن تقرير مراقب الحسابات فى حالاته

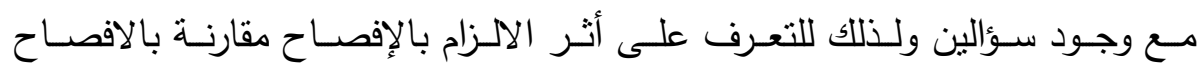
الاختبارى. حيث قام المستثمرون بتحديد مدى امكانية الاعتماد على التقربر والتغير

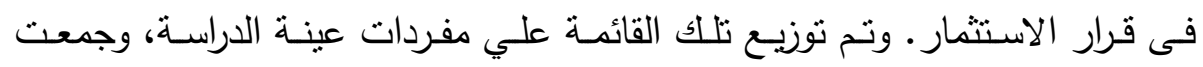

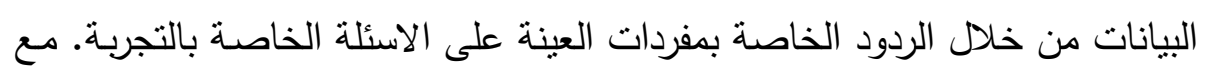

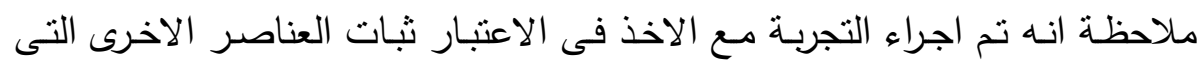

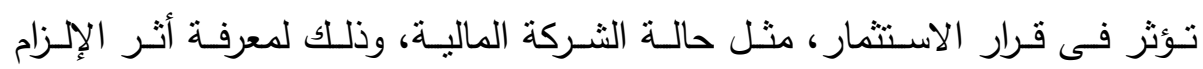
بالإفصاح عن اسم الثريك فى تقرير مراقب الحسابات على قرار الاستثمار فقط.

\section{4- توصيف وقياس متغيرات الدراسة :}

أـ المتغير المستقل : الإلزام بالإفصاح عن اسم شريك المراجعة في تقرير مراقب : توفي

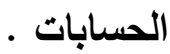

يعرف شريك المراجعة وفقا للمعيار الدولى 220 ISA بأنه الثريك أو الثخص الاخر فى المكتب، المسئول عن ارتباط المراجعة و الاداء وجودة عملية المراجعة و تقرير مراقب الحسابات الذى يتم اصداره نيابة عن مكتب المراجعة ، كما يعرفه المعيار أيضاً بأنه الثخص الذى يقوم بالحفاظ على اتصـال منتظم مع الادارة ولجنة

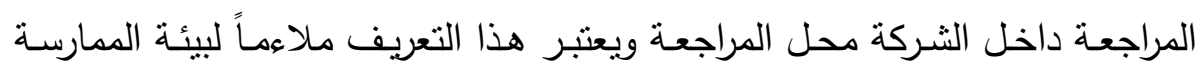

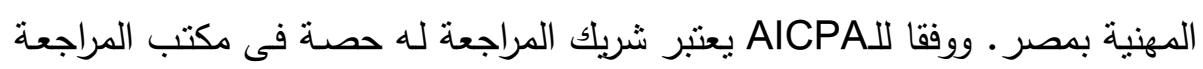
وبالتالى له نصيب من الارباح بناءا على حصته(1). وتم قياس هذا المتغير من خلال الإلزام بالإفصساح (عدم الإلزام بالإفصاح) عن اسم شريك المراجعة بالتقرير (متغيرين

(1) يمكن الرجوع إلى ترتيب الوظائف وتعريف كل وظيفة داخل مكتب المراجعة بالنسبة لمراقب الحسابات حتى الثريك http://www.aicpa.org/CAREER/CAREERPATHS/PUBLICACCOUNTING/Pages/def ault.aspx 
وهميين إلزام بالإفصـاح عنه (1) عدم الإلزام بالإفصـاح عنه (0) قياساً على دراسة

. (Veena\&Jodi , 2016)

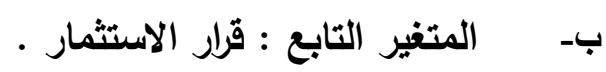

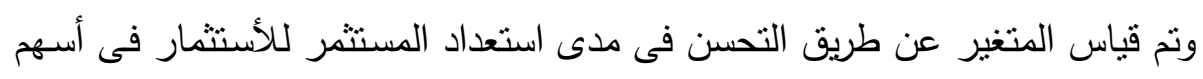

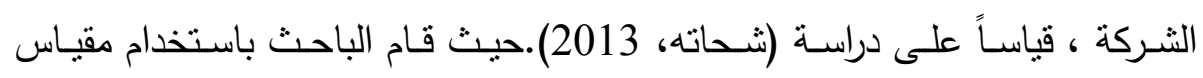

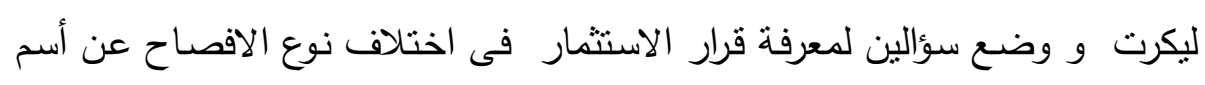

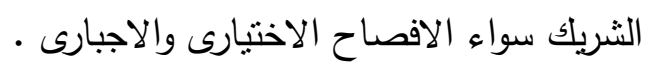

5- 5 المعالجات التجريبية :

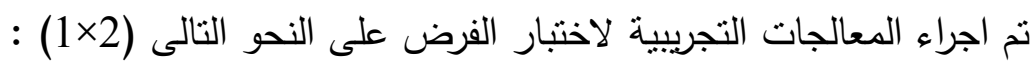

\begin{tabular}{|c|c|c|}
\hline الاجبارى (الجديد ) & الاختبارى (القديم) & الإلزام بالإفصاح من عدمه \\
\hline قرار الاستثمار (2) & قرار الاستثمار (1) & المستثرين \\
\hline
\end{tabular}

6- المقارنات بين المعالجات التجريبية لاختبار فروض الدراسة :

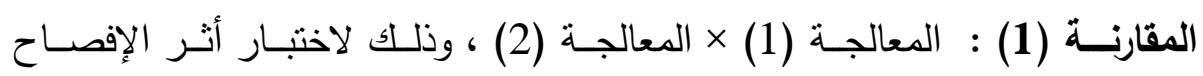

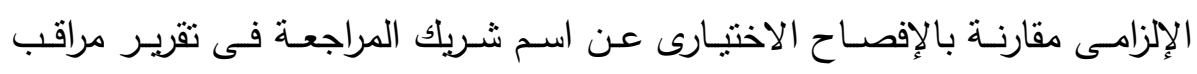

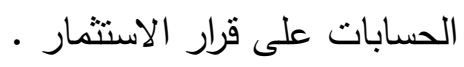

7-الأساليب الإحصائية المستخذمة:

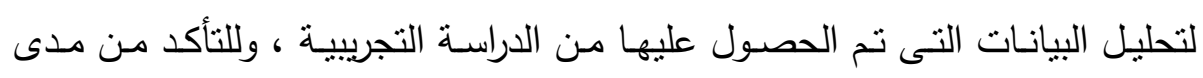

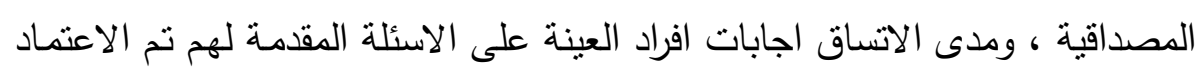

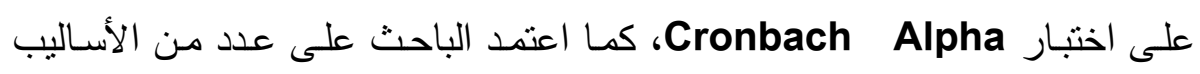

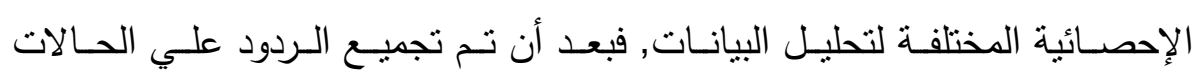

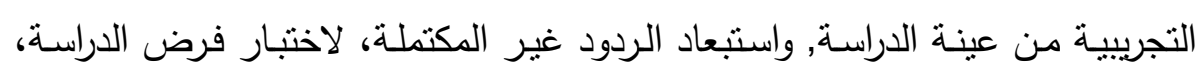


قام الباحث باستخدام برنامج الاكسيل لتفريغ ردود المفردات المشاركة في التجربة، ثم

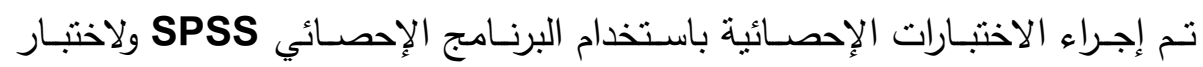

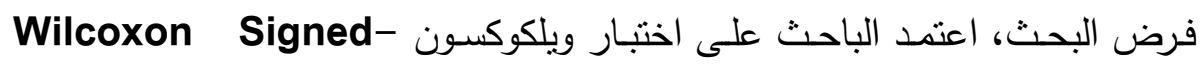
Rank Test ألفا يبلغ (0.701 ) ), وهو ما يعكس مستوى جيد من الصدق والثبات.

Reliability Statistics

\begin{tabular}{|r|r|}
\hline Cronbach's Alpha & N of Items \\
\hline .701 & 2 \\
\hline
\end{tabular}

كمـا تم اختبـار مدي اعتداليـة البيانـات، باستخدام اختبـار كولمهوجروف_سمبرنوف

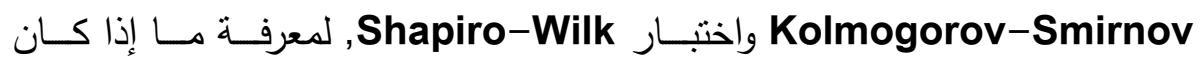
التوزيع الاحتمالى للمجتمع, الذى سحبت منه العينة, يتبع التوزيع الطبيعي أم لا. فإذا كانت قيمة P. value أكبر من 5\% يتم قبول فرض العدم، في حين أنه إذا كانت

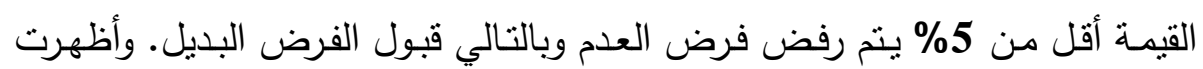

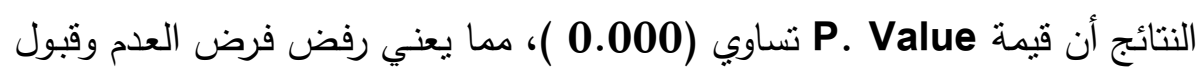

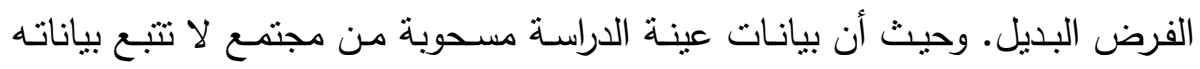
التوزيع الطبيعي سيتم استخدام الاساليب اللامعلمية لاختبار فرض البحث.

Tests of Normality

\begin{tabular}{|l|c|c|c|c|c|r|}
\hline & \multicolumn{3}{|c|}{ Kolmogorov-Smirnov ${ }^{\text {a }}$} & \multicolumn{3}{c|}{ Shapiro-Wilk } \\
\cline { 2 - 7 } & Statistic & Df & Sig. & Statistic & df & Sig. \\
\hline VAR00001 & .303 & 41 & .000 & .845 & 41 & .000 \\
VAR00002 & .255 & 41 & .000 & .824 & 41 & .000 \\
\hline
\end{tabular}

a. Lilliefors Significance Correction 
8-نتيجة اختبار فرض البحث:

واستهدف فرض البحث اختبار ما إذا كان الإلزام بالإفصاح يؤثز إيجاباً بدرجة اكبر مقارنة بالإفصاح الاختبارى عن اسم شريك المراجعة فى تقرير مراقب الحسابات

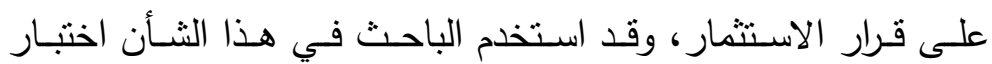
Wilcoxon كفرض عدم H لا يؤثر الإلزام بالإفصـاح ايجابياً بلرجـة اكبر مقارنـة بالإفصـاح الاختيـارى عن اسم شريك المراجعة فى تقرير مراقب الحسابات على قرار الاستثمار.

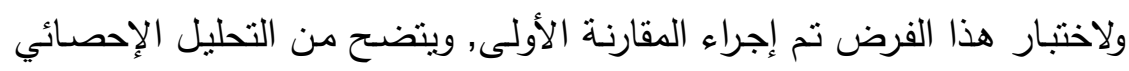
أن قيمة P.Value لهذا الاختبار تساوي ( 0.216) باستخدام اختبار Wilcoxon وهي نسبة أكبر من 5\% مما يعني قبول فرض العدم H م ، الإلزام بالإفصساح لا يؤثر

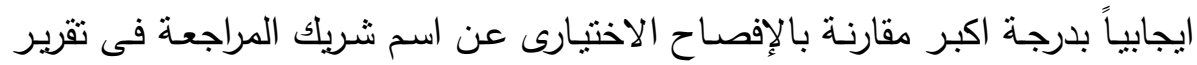
مراقب الحسابات على قرار الاستثمار ، وهو ما بعني رفض فرض الاراسة.

\begin{tabular}{|r|r|}
\hline & VAR00002 - VAR00001 \\
\hline $\mathrm{Z}$ & $-1.236-{ }^{\mathrm{b}}$ \\
Asymp. Sig. (2-tailed) & .216 \\
\hline
\end{tabular}

a. Wilcoxon Signed Ranks Test b. Based on negative ranks.

النتائج والتوصيات ومجالات البحث المقترحة: فيمـا يلي عرض لنتائج البحث بشقيه النظري والتطبيقي، وتوصيات البحث، بالإضـافة لبعض المجالات البحثيـة المقترحة التي يمكن تتاولها من قبل الباحثني، علي النحو التالي: 
رابعاً-نتائج البحث:

خلص الباحث، علي مستوى الاراسـة النظريـة, إلي أنه نتيجةً لرغبـة مستخدمي

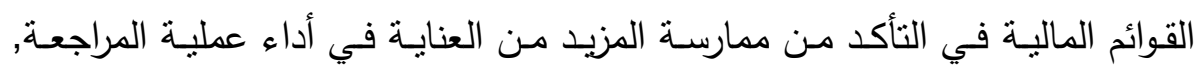

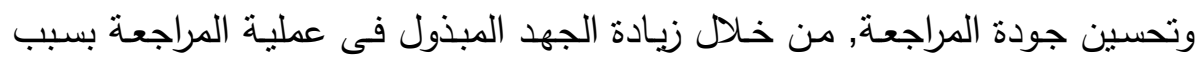

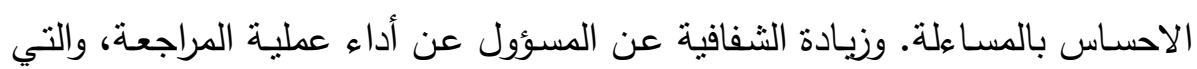

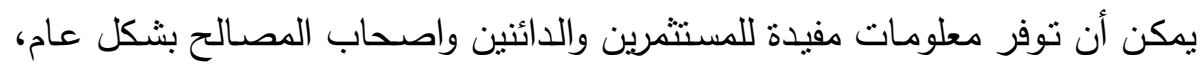

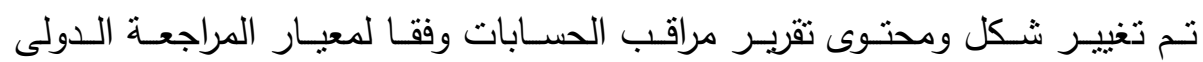
ISA700 المعدل لسنة 2015 ، من خلال إضافة فقرات جديدة وتعديل فقرات اخرى هرى قائمسة كاستجابة لنلك المتطلبـات. وفي ظل اعتمـاد المستثرون على تقرير مراقب الحسـابات بشكل كبيـر، فــن المتوقـع أن يـؤثر أى تعديل في التقريـر على القرار

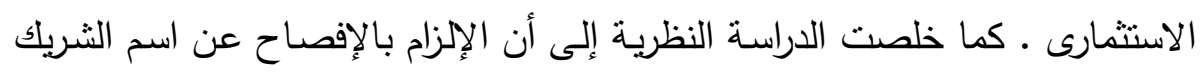

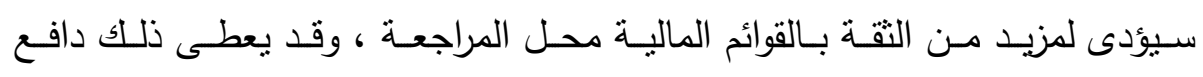

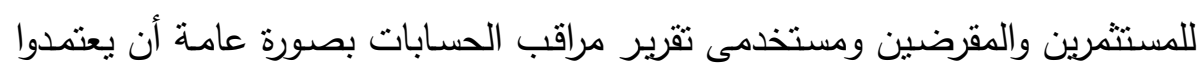
بصورة أكثر على التقرير ،علما بأن تلك العلاقة قد تتأثز بعدد من المتغيرات الرقابية

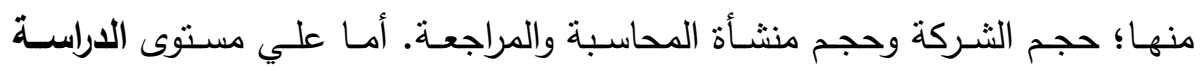
التجريبية فقد تبين أن الإلزام بالإفصاح لا يؤثز ايجابياً بدرجة اكبر مقارنـة بالإفصاح

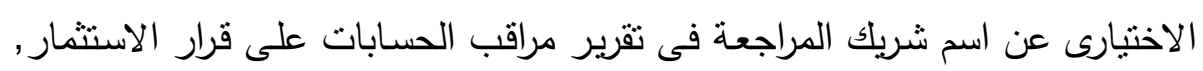
في بيئة الممارسة المهنية المصرية.

\section{خامساً-1- ت توصيات البحث:}

في ضوء ما تم التوصل إليه من نتائج يوصي الباحث بما يلي:

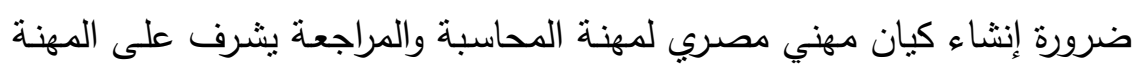
وينظمها ويصدر ويعدل معايير المحاسبة والمراجعة، وفق مدخل التوفيق لبيئة الممارسة المهنية المصرية. 
ضــرورة قيـام منشـآت المحاسبة والمراجعـة بـالإلتزام بالإفصـاح عـن اسـ شـريك المراجعـة في تقارير المراجعـة، لضمان جودة المراجعة, والاتسـاق فـى الافصـاح وزيادة ثقة المستثمرين. أن تقوم هيئة الرقابـة المالية بالضـغط على منشـآت المحاسبة والمراجعة للإلتزام

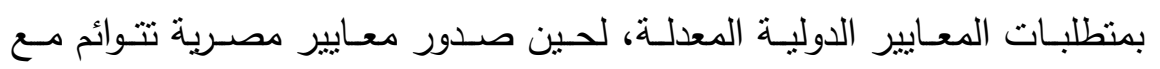
الدولية.

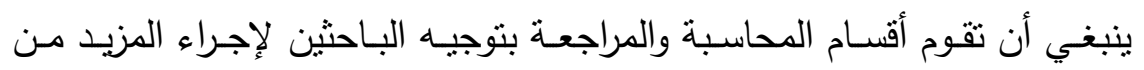

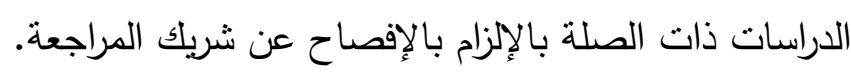

\section{2-مجالات البحث المقترحة:}

بناءً على ما خلصت إليه الدراستين النظريـة والتجريبية من نتائج، ووفقاً لهدف البحث وحدوده، يمكن اقتراح عدد من مجالات البحث المستقبلية، وذلك على النحو

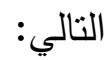

العلاقة بين الإفصاح عن اسم شريك المراجعة ووجود الغش في القوائم المالية، دراسة تطبيقية على الشركات المقيدة بالبورصة المصرية. أثز الإفصاح عن اسم شريك المراجعة على قرارات منح الإئتمان، دراسة تجريبية.

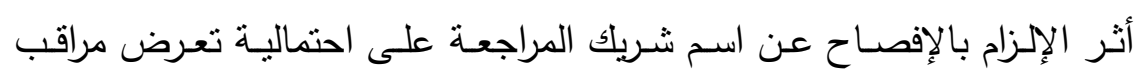
الحسابات لمخاطر التقاضي.

العلاقة بين الإفصساح عن اسم شريك المراجعـة وجودة التقارير الماليـة، دراسـة تطبيقية علي الثركات المقيدة بالبورصة المصرية. 
قائمة المرلحع المستخدمة في اعدادالبحث أولاً :المراجع العربية :

السيد ، شحاته ،2013 , أثر توكيد مراقب الحسابات على إفصاح الثركات

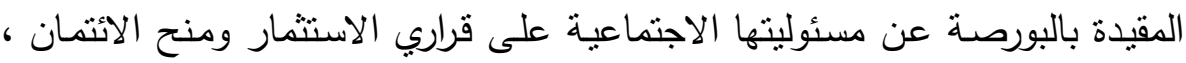

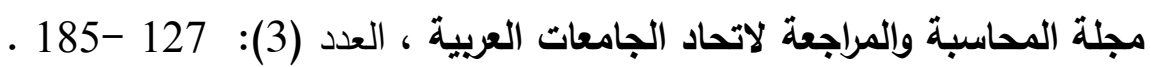
الحمود ، محمد ، 2011 ،" أثر تعديلات تقريـر مدقق الحسـابات على قرارات الاستثمار فى الشركات المدرجة فى بورصة عمان من وجهتى نظر مدققى الحسابات

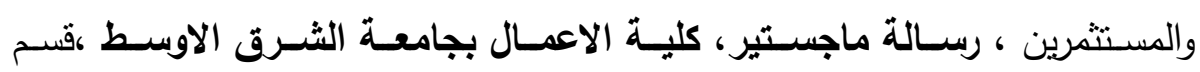

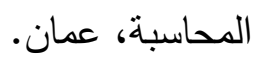

الزبديـة، رامسي محمد، وعلي عبد القادر الذنيبات، 2012، " أثر تقربر المدقق الخارجي في إتخاذ القرار الإيتماني في البنوك التجارية الأردنية"، المجلة الأردنية في إدارة الأعمال، المجلا الثامن، العدد الثالث، ص: 465 -494. •رزى، المنتصر باله سهيل نقولا، 2013، "أثز تعديلات معيار المراجعة الدولي

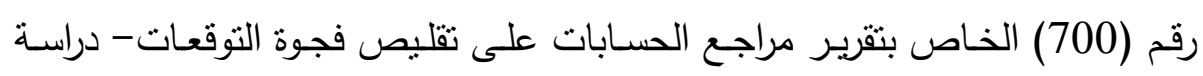

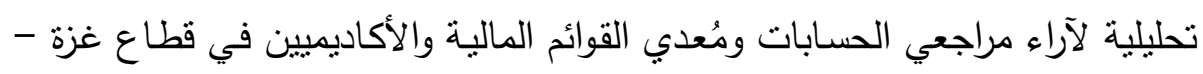

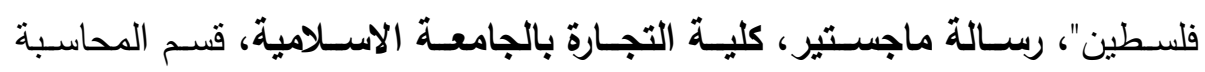
والتمويل، غزة. • خداش، حسام الدين؛ ابراهيم سليمان عمر الزوى، محمود نصسار، 2011، "اثر تعديلات معيار التدقيق الدولى رقم 700 المعدل والخاص بتقرير المدقق على تضييق

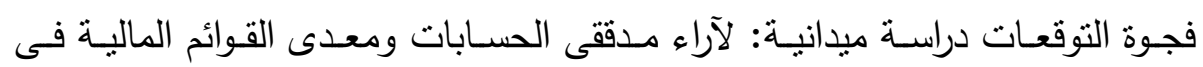

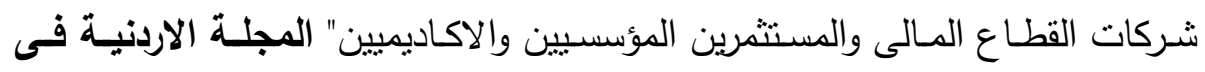

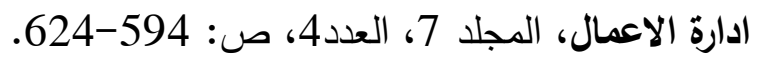




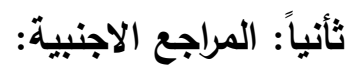

- AICPA, 2013 ,Proposals to Enhance the Auditor's Report , Available at aicpa.org/FRC

- Barmaky , J. Medora - (2015) , New and Revised auditor reporting standards enhancing communicative value, Available at : http://www2.deloitte.com/sg/en. Deloitte Singapore

- Bédard, J., Coram, P., Espahbodi, R., \& Mock, T. J. (2015). Does Academic Research Provide Sufficient Evidence in Support of Changes to the Audit Reporting Model?. Available at: http://ssrn.com/2631676.

- Bierstaker, J. L., Elder, R. J., Abbott, L. J., Caster, P., Firer, S., Parker, S. \& Reed, B. J. (2009), 'Auditing Standards Committee comment letter. PCAOB Rulemaking Docket Matter No. 029: Concept release on requiring the engagement partner to sign the audit report', Current Issues in Auditing, Vol. 3, No. 2 : 11-19.

- Boolaky.k, (2016), Bank Directors' Perceptions of Expanded Auditor'sReports, International Journal of Auditing,Available at ISSN 1090-6738

- Blay, A. D., Gooden, E. S., Mellon, M., Stevens, D. E. (2013), 'Can moral reasoning reduce auditor misreporting? An experimental investigation of investor presence and an auditor sign requirement', Working Paper, Florida State University. 
- Blay, A. D., Notbohm, M., Schelleman, C., \& Valencia, A. (2014). Audit quality effects of an individual audit engagement partner signature mandate. International Journal of Auditing, 18(3) : 172-192.

- Blay, A., M. Notbohm, C. Schelleman, and A. Valencia. (2012). Audit quality effects of an individual audit engagement partner signature mandate. Available at: http://papers.ssrn.com/sol3/papers.cfm? abstract_id $1 / 42044817$.

- Carcello, J. V., \& Li, C. (2013). Costs and benefits of requiring an engagement partner signature: Recent experience in the United Kingdom. The Accounting Review, 88(5), 1511-1546.

- CFA Institute.( 2011). Usefulness of the Independent Auditor's Report: Survey to the CFA Institute Financial Reporting Survey Pool. Retrieved from : http://www.cfainstitute.org/Survey/usefulness_of_independen t_auditors_report_survey_results_march_2011.pdf .

- Chen, C., Lin, C. \& Lin, Y. (2008), 'Audit partner tenure, audit firm tenure, and discretionary accruals: Does long auditor tenure impair earnings quality? Contemporary Accounting Research, Vol. 25, No. 2,: 415-445.

- Chi, H.-Y., and C.-L. Chin.( 2011). Firm versus partner measures of auditor industry expertise and effects on auditor 
quality. Auditing: A Journal of Practice \& Theory 30 (2): 201-229.

- Chi, W., Myers, L. A., Omer, T. C., \& Xie, H. (2011), The effects of audit partner pre-client and client-specific experience on audit quality and on perceptions , Available at SSRN: http://ssrn.com/abstract $=1304953$

- Coram, P. (2014), 'Audit reports', Available at: http://papers.ssrn.com/sol3/papers.cfm?abstract_id=251195 -

- Daniel , J. Gravina .(2014) , Proposed Audit Reporting Changes: Considerations of Stakeholders' Perspectives , Working Paper. Available at :http://scholars.unh.edu/cgi/viewcontent.cgi?article=1187\&co ntext=honors

- Davis, S., R. King, and N. Mintchik. (2012). Mandatory disclosure of the engagement partner's identity: Potential benefits and unintended consequences. Accounting Horizons 26 (3): 533-561.

- Elder, R. J., Beasley, M. S., \& Arens, A. A. (2011). Auditing and Assurance services. Pearson Higher Ed.

- Fargher, N., Lee, H. \& Mande, V. (2008), 'The effect of audit partner tenure on client managers' accounting discretion', Managerial Auditing Journal, Vol. 23, No. 2, 161-186. 
- Gold, A., Lindscheid, F., Pott, C. \& Watrin, C. (2012), 'The effect of audit engagement and review partner rotation on audit quality: Evidence from Germany', Working Paper, VU University Amsterdam.

- Gómez, Antonio ,(2013), "The usefulness of the audit report in investment and financing decisions", Managerial Auditing Journal, Vol. 18 Iss: 7 : 549 - 559 .

- International Journal of Disclosure and Governance, 7 (4): 344-363

- IAASB , INTERNATIONAL STANDARD ON AUDITING 220 QUALITY CONTROL FOR AN AUDIT OF FINANCIAL STATEMENTS .

- IAASB ,2015) , ISA 700 forming an opinion and Reporting on Financial statements .

- Institute of Singapore chartered accountants (2015) , Background of the IAASB Project, Available at : http://isca.org.sg/tkc/aa/current-issues/hot-topics/auditorreporting/

- Ittonen, K. (2012). A theoretical examination of the role of auditing and the relevance of audit reports. Working Paper, University of Vaasa, Finland.

- Jeffrey , L Johanns, (2015) , More audit transparency for investors makes a bitter proposal easier to swallow. Available at : http://theconversation.com/more-audittransparency-for-investors-makes-a-bitter-proposaleasier-to-swallow-46067 
- Kyungha (Kari) ,Lee,(2015) ,Audit Partner Identi.cation and Audit Quality ,working paper, Rutgers Business School.

- Lambert, T., Luippold, B. \& Stefaniak, C. (2015), Audit Partner Disclosure: An Experimental Exploration of Accounting Information Contagion, Available at SSRN:http://ssrn.com/abstract=1983482

- Lambert, T., Luippold, B., \& Stefaniak, C. (2012). Audit partner disclosure: Potential implications for investor reaction and auditor independence. Working paper, University of Massachusetts Amherst.

- Mock, T. J., Bédard, J., Coram, P. J., Davis, S. M., Espahbodi, R., \& Warne, R. C. (2013). The audit reporting model: Current research synthesis and implications. Auditing: A Journal of Practice \& Theory, 32(sp1), 323-351.

- Ojeka, S.,(2011), Analyzing The Relationship between Auditor's Report and Shareholders' Investment Decision , Lambert Academic Publishing Gmbh \& Co. KG Germany.

- PCAOB ,2013) ,improving the transparency of audit :proposed amendments to Pcaob Auditing Standards to provide disclosure in the auditor report of certain audit participants, PCAOB Release No. 2013-009 December 4, 2013

- PCAOB ,2015), improving the transparency of audits rules to require disclosure of certain audit participants on a new 
أثث الإلزام بالإفصاح عن اسم شريك المراجعة فى تقرير مراقب الحسابات على قرار الاستثمار

pacob form and related amendments to Auditing Standards. PCAOB Release No. 2015-008 December 15, 2015

- PCAOB(2016) PCAOB Rules to Improve Transparency by Disclosing Engagement Partner Name and Information about Other Audit Firms are Approved by SEC Available at : https://pcaobus.org/News/Releases/Pages/SEC-approvestransparency-Form-AP-051016.aspx

- Public Company Accounting Oversight Board (PCAOB) (2009a), 'Improving transparency through disclosure of engagement partner and certain other participants in audits'. Available at http:/pcaobus.org/Rules/ Rulemaking/Pages/Docket029.aspx .

- Reid, L. C., Carcello, J. V., Li, C., \& Neal, T. L. (2015). Are auditor and audit committee report changes useful to investors? Evidence from the United Kingdom. ? Available at:

https://papers.ssrn.com/sol3/papers.cfm?abstract_id=2637880

- Schatzberg, J. W., Sevcik, G. R., Shapiro, B. P., Thorne, L., \& Wallace, R. O. (2005). A reexamination of behavior in experimental audit markets: The effects of moral reasoning and economic incentives on auditor reporting and fees. Contemporary Accounting Research, 22(1), 229-264.

- Simnett .H (2014), Enhancing the Auditor's Report: To What Extent is There Support for the IAASB's Proposed Changes? Accounting Horizons, Vol. 28, No. 4, : 719-747 . 
- Veena L. Brown, Jodi L. Gissel,(2016) , effects of Mandatory Disclosure of Audit Engagement Partners, ? Available at: http://papers.ssrn.com/sol3/papers.cfm?abstract_id=2831730

- Zerni, M. (2012). Audit partner specialization and audit fees: Some evidence from Sweden. Contemporary Accounting Research, 29(1), 312-340. 


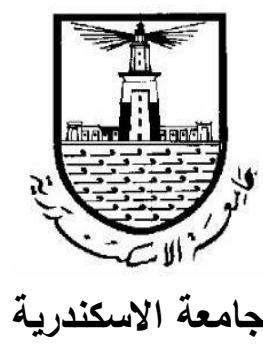

كلية التجارة

قسم المحاسبة والمراجعة ملحق (1) الدراسة التجريبية

قائمة خاصة بالتجربة البحثية عن موضوع: أثر الإلزام بالإفصاح فى تقرير مراقب الحسابات عن أسم شريك المراجعة على على قرار الاستثمار السيد الاستاذ العزيز / /....................................................... تحية طيبة وبعد ، ، تسريز

تهدف هذه الدراسة إلى التعرف على أثز الإلزام بالإفصاح فى تقرير مراقب الحسابات

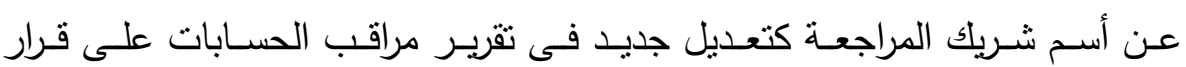

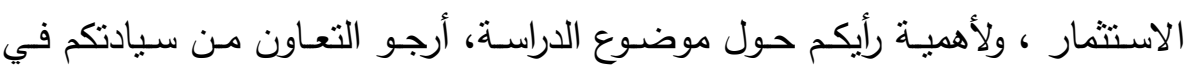

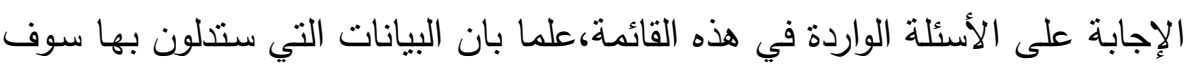

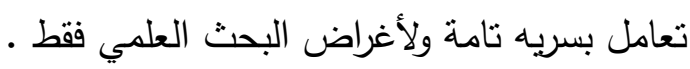

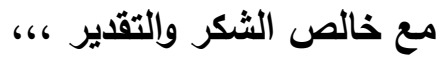

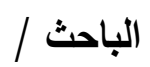

على حسن على ابراهيم السمسار

معيد بقسم المحاسبة وإلمراجعة

كلية التجارة جامعة الاسكندرية 
القسم الأول: البيانات الثخصبة

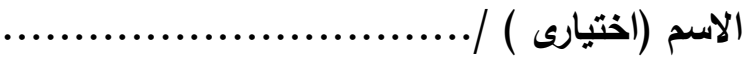

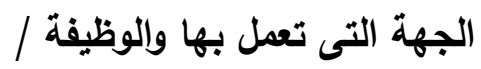

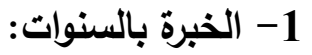

口 أقل من 5 سنوات

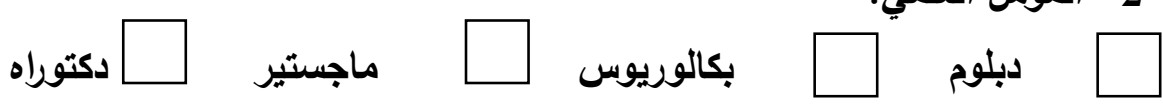

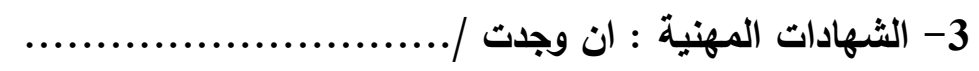

يقوم الباحث بدراسـة أثر تعديل مـن التعديلات الجديدة وفقات للمعيـار الدولى 700

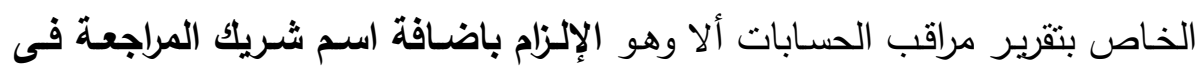
تقرير مراقب الحسابات ، على قرار الاستثمار .

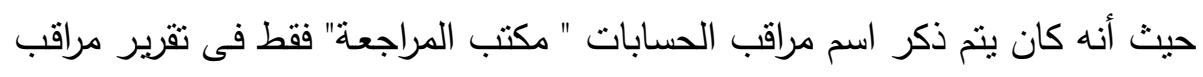

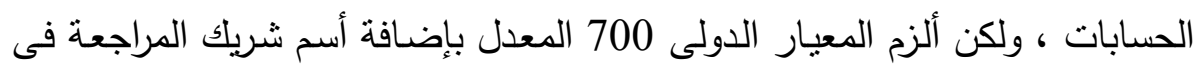

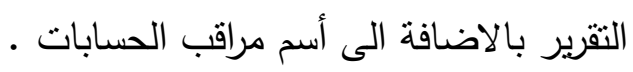
ويمكن توضيح الفرق بين شريك المراجعة ومراقب الحسابات كالتالى :

• شريك المراجعة : الثخص الموجود فى مكتب المراجعة المسئول عن الاثراف

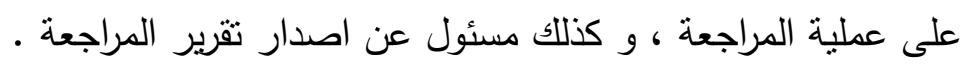

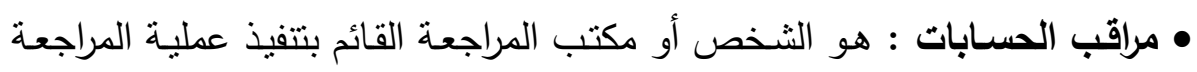

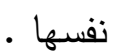




\section{الحالة الأولىى}

بـافتراض ان الثـركة (س) شـركة مسـاهمة مقيدة بالبورصـة ، وقـد تسـلمت القوائم

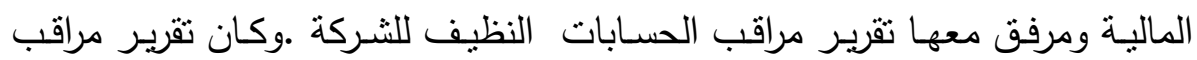

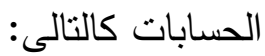

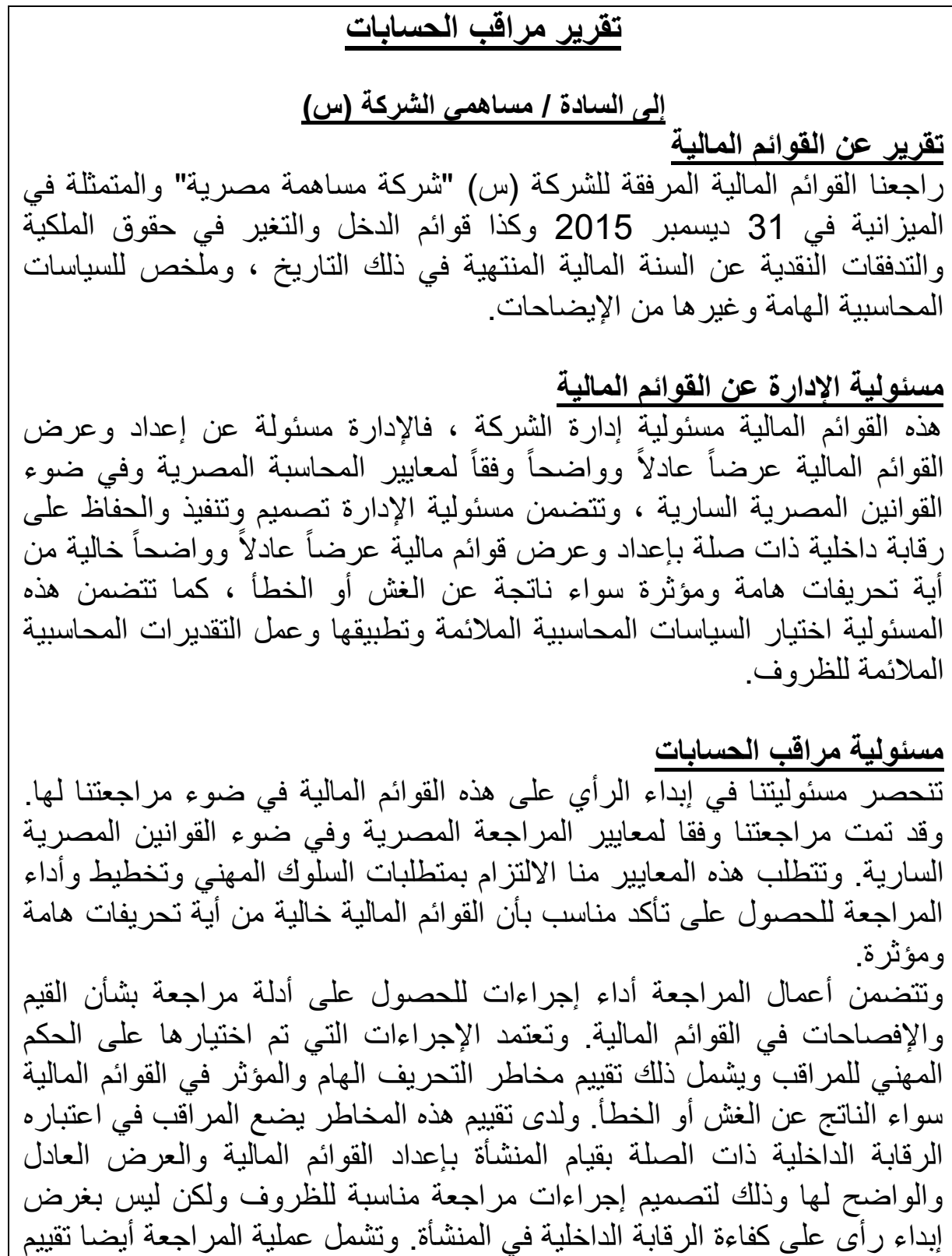


مدى ملائمة السياسات المحاسبية والتقديرات المحاسبية الهامة التي أعدات بمعرفة

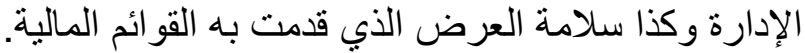

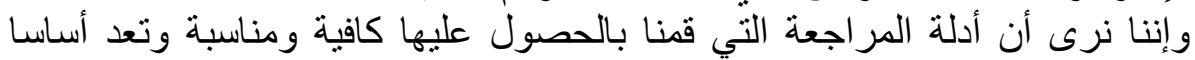
مناسبا لإبداء ر أينا على القوائم المالية.

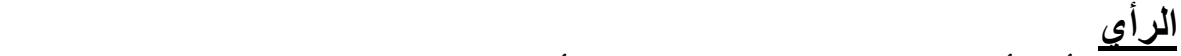
وون رأينا أن القوائم المالية المشار إليها أعلاه تعبر بعدالة ووضوح في المبالة ، في جميع

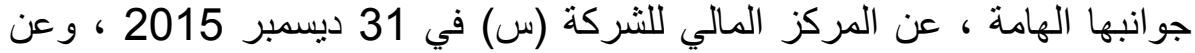

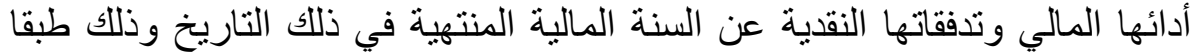

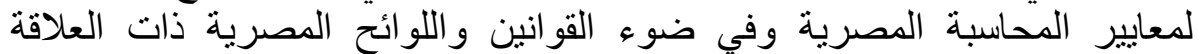
بإعداد هذه القو ائم المالية.

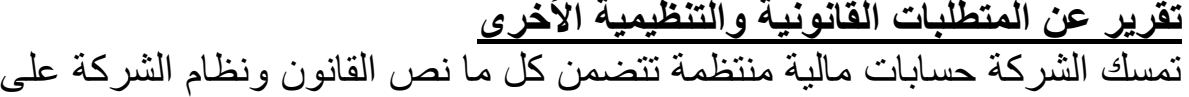

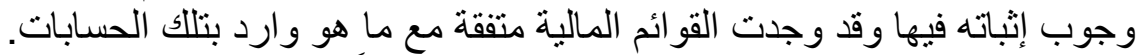

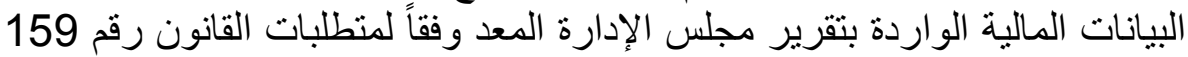

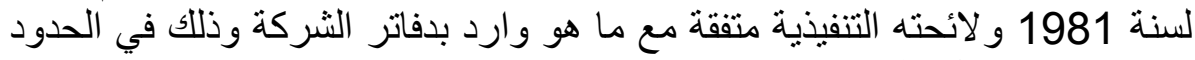

\section{توقيع مراقب الحسابات} التي تتبت بها مثل تلك البيانات بالدفاتر . المجمو عة المصرية للمر افعة البماتيات

أسم شريك المراجعة

شادى زعتر

فى ضوء تقرير مراقب الحسابات للشركة(س) ، ومعرفتلك ان الافصـاح عن أسـم شريك المراجعة اختيارياً فى التقرير ، فاجب عن التالى:- 


\begin{tabular}{|c|c|c|c|c|}
\hline غير موافت تماماً & غير موافق & محايد & موافق & موافت تماماً \\
\hline & & & & \\
\hline
\end{tabular}

الحالة الثانبة(حالة الافصاح الإلزامى عن شريك المرجعة) اذا علمت أنه صدر قرار من هيئة الرقابة المالية يلزم الثركات بضرورة نوقيع شريك الكئك المراجعة على تقرير المراجعة وبافتراض نفس البيانات الخاصة بالثـركة (س) بالاضـافة انه تم الافصـاح عن أسم

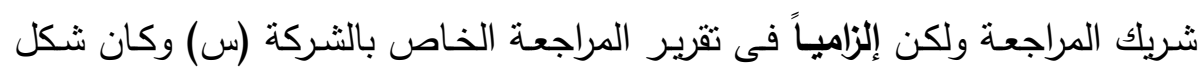
فقرة الرأى فى التقرير كالتالى:

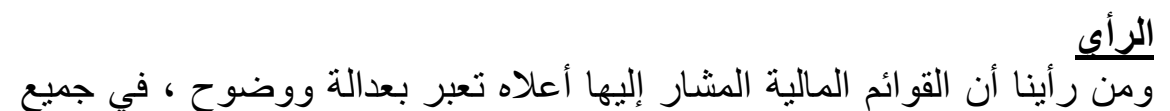

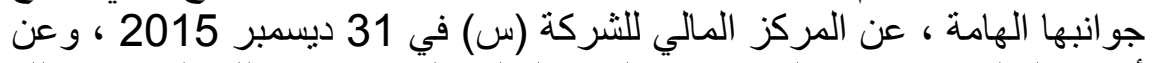

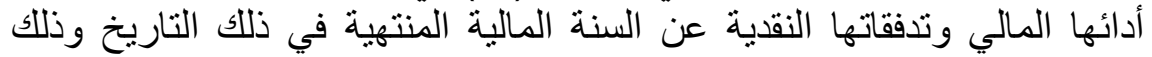

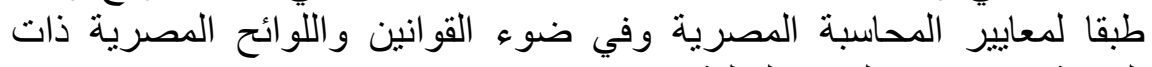

\section{توقيع مراقب الحسابات} العلاقة بإعداد هذه القوائم المالية.

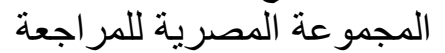

أسم شريك المراجعة المراجة

شادى ز زئر المر

\section{القاهرة في 26 فبر اير 2016}

فى ضوء ثقرير مراقب الحسابات للشركة(س) ، ومعرفتك ان الافصـاح عن أسـم شريك المراجعة إلزامباً فى التقرير ، أجب عن النالى :1/ ماهو مدى موافقتك على الاستثمار فى أسهم الثركة (س)؟

\begin{tabular}{|l|l|l|l|l|}
\hline موافق تماماً & غوافير موافق تماماً & & \\
\hline & & & & \\
\hline
\end{tabular}


ملحق (2) عينة من تقارير مراقبى الحسابات الشركات المقيدة بالبورصة المصرية

\begin{tabular}{|c|c|c|c|c|c|}
\hline لا تفصح & تفصح & اسم الشريك أن & اسم المراقب أو & اسم الثركة & p \\
\hline$\sqrt{ }$ & & & مجدى حشيش & 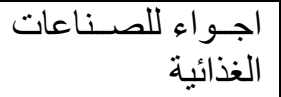 & 1 \\
\hline$\sqrt{ }$ & & & حازم حسن & و التنمية و التعمير للإسكان & 2 \\
\hline$\sqrt{ }$ & & & وحمود الحشـاش الغفـار & الثرقيون للسجـادون & 3 \\
\hline & $\sqrt{ }$ & نميــل راغـــنبولى & $E \& Y$ & السويس للاسمنت & 4 \\
\hline$\sqrt{ }$ & & - & هثـام حسبو & الدلتا للسكر & 5 \\
\hline & $\sqrt{ }$ & نصر ابو العباس & موريسون & للالاســاعيلية دصـر & 6 \\
\hline & $\sqrt{ }$ & شاتر منتصر الدين & $\begin{array}{r}\text { Moore } \\
\text { stphens } \\
\text { حازم حسن }\end{array}$ & حديد عز & 7 \\
\hline$\sqrt{ }$ & & & 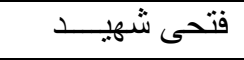 & الاتحاد التجارية & 8 \\
\hline & $\sqrt{1}$ & فربد الناصــــــــــــن & $\begin{array}{r}\text { Moore } \\
\text { stphens }\end{array}$ & EBE & 9 \\
\hline & $\sqrt{1}$ & محمد ابر اهيم & E\&Y & القابضة للتأمين & 10 \\
\hline$\sqrt{ }$ & & - & - & غازتلك Gastec & 11 \\
\hline$\sqrt{ }$ & & - & حازم حسن & أعمال للمقاو لات & 12 \\
\hline & $\sqrt{1}$ & جوزيــف & $E \& Y$ & أر امكس & 13 \\
\hline & $\sqrt{1}$ & هشام الافندى المعتـــز & $\begin{array}{r}\text { PWC } \\
\text { حازم حسن }\end{array}$ & كريدى اجريكول & 14 \\
\hline & $\sqrt{1}$ & - & $\begin{array}{r}\text { PWC } \\
\text { DEloitte }\end{array}$ & اتصـالات & 15 \\
\hline & $\sqrt{1}$ & - & E\&Y & 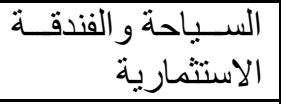 & 16 \\
\hline$\sqrt{ }$ & & - & حازم عبد التو اب & نادى الزماللك & 17 \\
\hline & $\sqrt{1}$ & حاتم منتصر & حازم حسن & غبور للسيار ات & 18 \\
\hline & $\sqrt{1}$ & سايمى مقلد ابــر اهيم & PWC & ثالأور اقــــار لتـــــــاول & 19 \\
\hline$\sqrt{ }$ & & & حازم حسن & المصـريين للأنشــاء & 20 \\
\hline
\end{tabular}


أثر الإلزام بالإفصاح عن اسم شريك المراجعة فى تقرير مراقب الحسابات على قرار الاستثمار

\begin{tabular}{|c|c|c|c|c|c|}
\hline لا تفصح & تفصح & اسم الشريك أن & اسم المراقبّ أو & اسم الشركة & p \\
\hline & & & & و والتعمير & \\
\hline & $\sqrt{ }$ & مصطفى شوقى & $\mathrm{E \& Y}$ & مينـــــــاسلاســـثمار & 21 \\
\hline$\sqrt{1}$ & & & E\&Y & الكصبرية الكهربائية & 22 \\
\hline$\sqrt{1}$ & & - & عحمد الحكيم المـنعم سـلام & 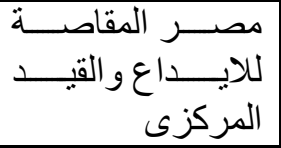 & 23 \\
\hline & $\sqrt{ }$ & حاتم منتصر & حازم حسن & 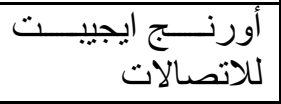 & 24 \\
\hline$\sqrt{1}$ & & & 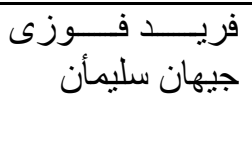 & 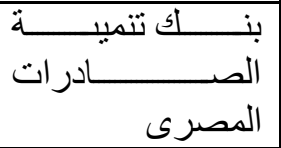 & 25 \\
\hline$\sqrt{1}$ & & - & - & أنبى & 26 \\
\hline$\sqrt{ }$ & & & حازم حسن & للاتصالات المصـــرية & 27 \\
\hline$\sqrt{1}$ & & - & - & سامسونج ايجييت & 28 \\
\hline & $\sqrt{1}$ & 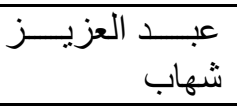 & E\&Y & الوحيــــــــاولات للمقات & 29 \\
\hline$\sqrt{1}$ & & - & مالك وشر كاؤه & سلغو هاج للصناعات & 30 \\
\hline & $\sqrt{ }$ & منصركاؤه & PWC & للزاجـــرق الأوســــ & 31 \\
\hline$\sqrt{1}$ & & & سمير الدلجاوى & للخدمات الطبية كندرية & 32 \\
\hline$\sqrt{1}$ & & & E\&Y & ابو قير للاسمدة & 33 \\
\hline$\sqrt{ }$ & & DEloitte & صالح عبد العزيز & المهندس للتأمين & 34 \\
\hline$\sqrt{1}$ & & & حازم حسن & 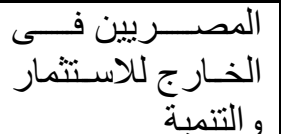 & 35 \\
\hline$\sqrt{ }$ & & & الجهاز المركزى & الاسكندرية للأدوية & 36 \\
\hline$\sqrt{1}$ & & & اسماعيل الملاحى & 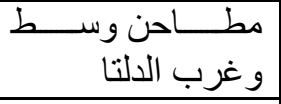 & 37 \\
\hline & $\sqrt{ }$ & فالسميع & E\&Y & 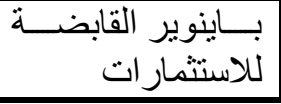 & 38 \\
\hline
\end{tabular}




\begin{tabular}{|c|c|c|c|c|c|}
\hline |لا تفصح | & تفصح & اسم الثريك أن & اسم المر اقب أو & اسم الشركة & م \\
\hline & $\sqrt{ }$ & 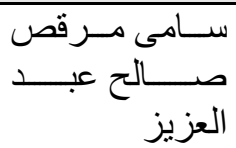 & 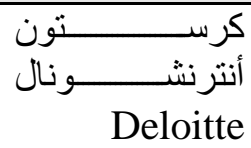 & دايس للملابس & 39 \\
\hline & $\sqrt{ }$ & مصطفى شوقى & S\&Y & بالم هبلز للاستثمار & 40 \\
\hline$\sqrt{ }$ & & & حازم حسن & العز للسير اميك & 41 \\
\hline$\sqrt{ }$ & & & الجهاز المركزى & مصر للالومنيوم & 42 \\
\hline$\sqrt{ }$ & & & $\overline{E \& Y}$ & السويس للأكياس & 43 \\
\hline$\sqrt{ }$ & & & عناني & الاهر ام للطباعة & 44 \\
\hline$\sqrt{ }$ & & & عناني & سكاي لايت للتنمية & 45 \\
\hline$\sqrt{ }$ & & & 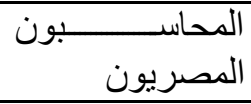 & 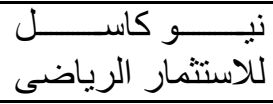 & 46 \\
\hline$\sqrt{ }$ & & & PWC & مستشفى كليو باتر ا & 47 \\
\hline$\sqrt{ }$ & & & رزق شندى & 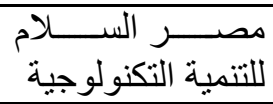 & 48 \\
\hline & $\sqrt{1}$ & منصوروشركاؤه & PWC & | ايديتا & 49 \\
\hline & $\sqrt{ }$ & 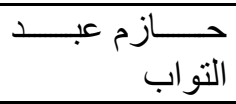 & حازم حسن & مرسليجية للعقار الـــرية & 50 \\
\hline & $\sqrt{1}$ & مصطفى شوفى & مز ارز & الفر اشَة للطباعة & 51 \\
\hline$\sqrt{ }$ & & & حازم حسن & للتمنية والاستثمار من اكتوبر & 52 \\
\hline & $\sqrt{1}$ & احمد سلطان & يور اوشركاؤه & الاسبتثمار العقـارى & 53 \\
\hline & $\sqrt{1}$ & نصر ابو العباس حشـيش & وشركاؤه & النشا والجلوكوزية لصـناعة & 54 \\
\hline$\sqrt{ }$ & & & احمد محمد نور & 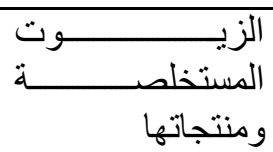 & 55 \\
\hline$\sqrt{ }$ & & & وُنأنى عبد عبد الغفـار & الزراعية للمحاصـيل & 56 \\
\hline & $\sqrt{1}$ & شريف دبوس & راسل بيدفورد & 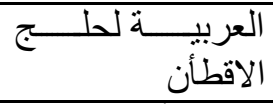 & 57 \\
\hline & $\sqrt{1}$ & محمد ناصف & ايه جى أن & رمكو لأنشاء القرى & 58 \\
\hline
\end{tabular}


أثر الإلزام بالإفصاح عن اسم شريك المراجعة فى تقرير مراقب الحسابات على قرار الاستثمار

\begin{tabular}{|c|c|c|c|c|c|}
\hline لا تفصح & تفصح & اسم الشريك أن & اسم المرأةب أو & اسم الشركة & r \\
\hline & & & & السياحية & \\
\hline & $\sqrt{ }$ & مصطفى شوقى & مزارز & 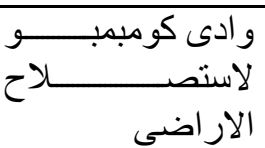 & 59 \\
\hline$\sqrt{ }$ & & & عنأنى & 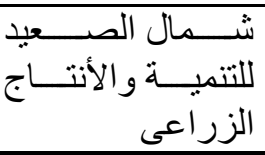 & 60 \\
\hline
\end{tabular}

نسبة التقارير المفصـح فيها عن اسم شريك المراجعة 45 \% ، والغير مفصـح

$$
\text { فيها عن اسم الشريك } 55 \text { \% }
$$

لايوجد أى إلزام بالإفصـاح عن اسم شريك المراجعة في بيئة الممارسـة المهنيـة المصرية الائ.

قد يكون شـريك المراجعـة المفصـح عنـه مـن Big Four أو قد لايوجد مـن ضمنهم.

• لا يتنم الإفصـاح في تقريـر مراقب الحسـابات عن اسـم شـريك المراجعـة بصـورة صريحة فى فقرة مستقلة فى النقرير ، وإنما يتم الإفصاح عن شريك المراجعة مع الإع اسم مراقب الحسابات الخاص بالثركة بالتقرير •

ملحق (3) اهم ماجاء فى معيار المراجعة 220 بشأن شريك المراجعة

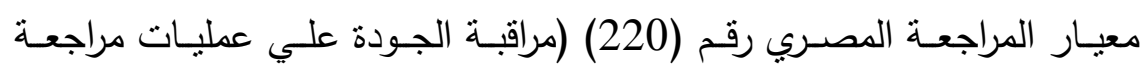
المعلومات المالية التاريخية) والذى يحدد المبادئ الاساسية للسلوك المهني، كما يقرر مسئوليات الثـريك المسئول المتعلقة بالمتطلبات السلوكية والاخلاقية، وينص معيار المراجعة المصري رقم (220) أنه يجب الاخذ فى الحسبأن امكانيات وكفاءات الافراد من خـلال تعيينهم وتـدريبهم الرسـي والاستقلالية وكذللك الحفاظ علي العلاقة مـع العملاء من خلال عملية الرقابة والتى يلعب شريك المراجعة دورا فيها ل 
وفيما يلي التعريف الخاص بشريك المراجعة الوارد في هذا المعيار : حيث عرف

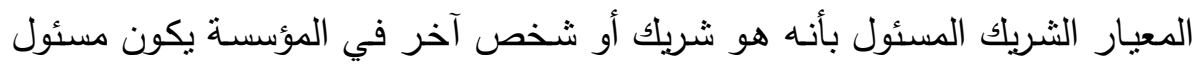

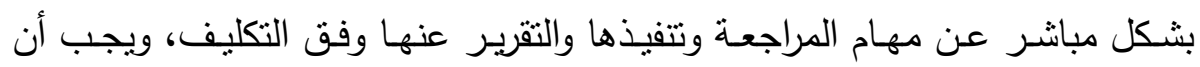

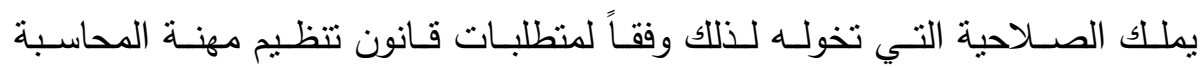
والمراجعـة. كما ذكر المعيار المتطلبات أو بعض الواجبات التى يجب على شريك المراجعة تتفيذها لتحقيق الجودة على أعمال المراجعة.

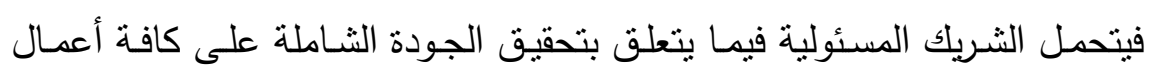

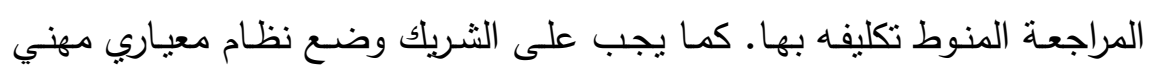

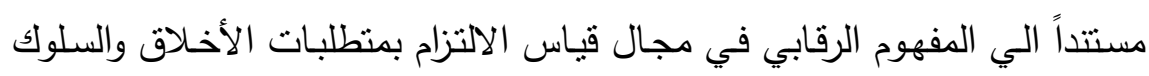
المهني من فبل فريق العمل حتى يمكنه تصحيح الانحرافات غير المتعددة ودعم الجوأنب الايجابيـة والحفاظ عليها، في إطلار هذا الالنزام الذي يكفل استمرارية

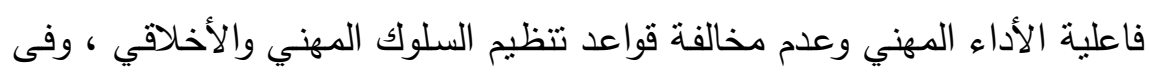
حال وجـود أنحرافات متعمدة في إطـار الالتزام بالمتطلبـات السلوكية والأخلاقيـة المهنية لفرد أو أفراد أو مجموعة فريق العمل بمكتب المراجعة يجب على الثريك الثرات

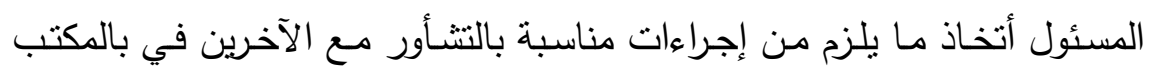

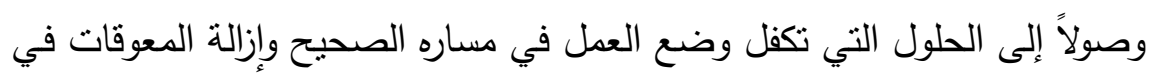
هذا المجال .

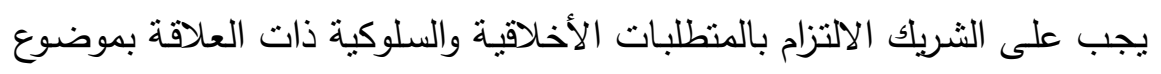

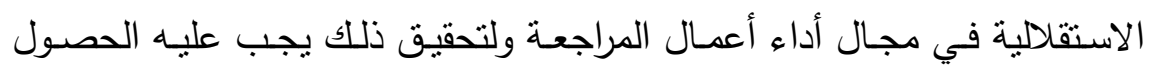
على المعلومات ذات الصلة من لتحديد وتقييم الظروف والارتباطات التي تشكل

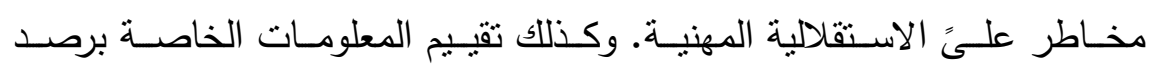

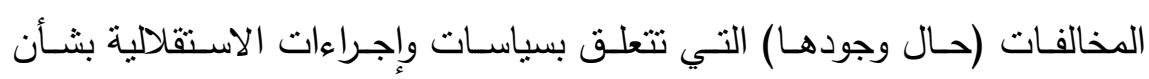
مراقبى الحسـابات، لتحديد مدى مخاطرها على استقلالية الأداء المهني لأعمال المراجعة. 
• على الثريك المسئول في مكتب المراجعة اتخاذ الإجراءات المناسبة للقضاء على مخاطر الاستقلالية أو تخفيضها لمستوي مقبول من خلال تطبيق إجراءات وقائية وفي حال عدم جدوى ما سبق فقد يجب عليه الانسحاب الكلي من هذه المهمة.

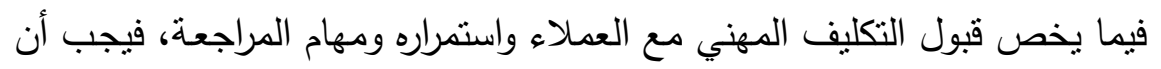
يشعر الثريك المسئول بالرضـا عن الإجراءات المناسبة المنبعة في مجال قبول

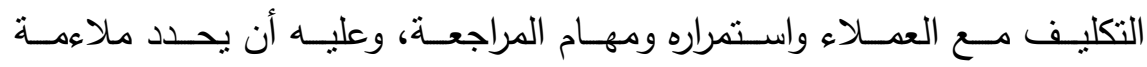
الاستتاجات التي نم التوصل إليها في هذا المجال.

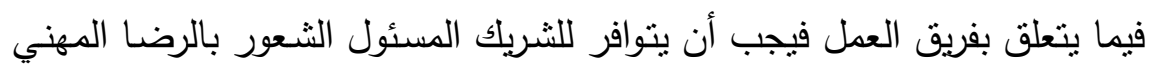

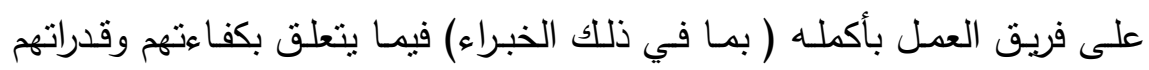

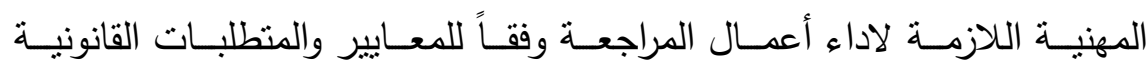
والتظظيمية بمايكفل للمكتب إصدار تقارير مراجعة ملائمة للظروف .

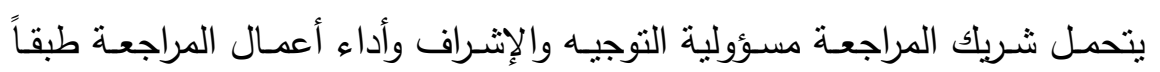
للمعايير المهنية والمتطلبـات القانونيـة والتتظيمية وإصدار تقرير المراجعة الملائم للظروف ـ كما يتحمل الثريك مسؤولية أعمال المراجعة التي نم أداءها . هجب على الثريك أن بشعر بالرضا عند إصدار تقرير المراجعة نتيجى ما قام بـه

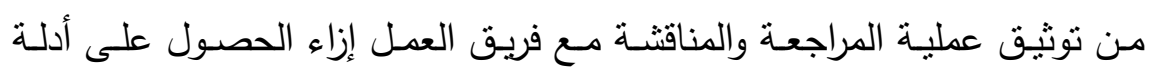

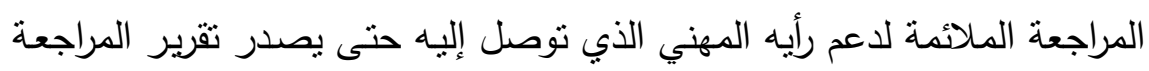

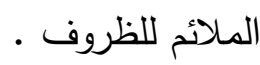
هينغي على الثريك تحمل مسئولية قيام فريق العمل بالمشأورات المهنية الملائمـة

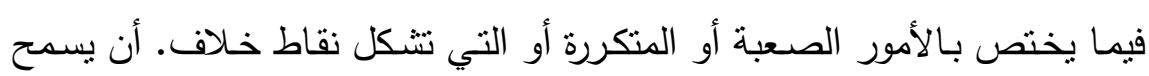

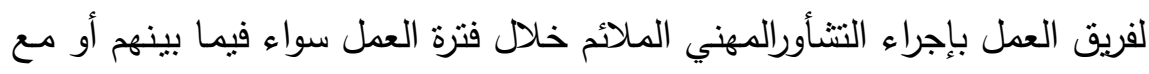
الغير في إطلار المهنية الملائمسة داخل مكتب المراجعة أو خارجهه. وأن يحدد مـاء إذا كانت النتائج التي أسفر عنها التشأور قد تم تتفيذها أو التأكيد على إمكانية 
ملحق (4) تقرير مراقب الحسابات المعدل وفقا لتعديلات IAASB فى يناير 2015 مقارنة بالتقريز القديم

التغييز في شكل "فقرات" تقرير مراقب الحسابات:-

\begin{tabular}{|c|c|}
\hline بعد التعديل & قبل التعديل \\
\hline 1. عنوان التقرير & 1. عنوان التقرير \\
\hline 2. الموجه البهم التقرير & 2. الموجه اليهم التقرير \\
\hline 3. فقرة الرأى & 3. الفقرة الافتتاحية \\
\hline 4. فقرة أساس الرأى & 4. فقرة مسئولية الادارة عن القوائم \\
\hline 5. فقرة الاستمرارية & 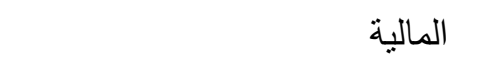 \\
\hline 6. فقرة امور المراجعة الأساسية (الجوهرية ) & 5. فقرة مسئولية مراقب الحسابات \\
\hline 7. قرة المعلومات الاخرى & 6. فقرة الرأى . \\
\hline 8. فقـرة مســـولية الادارة والمســـولين علــى & 7. فقرة أى متطلبات إلزامية اخرى \\
\hline الحوكمة عن القوائم المالية. & 8. توقيع مراقب الحسابات \\
\hline 9. فقرة مسئولية مراقب الحسابات عن مراجعة & 9. تاريخ تقرير مراقب الحسابات \\
\hline 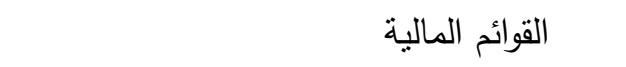 & 10. عنوان مراقب الحسابات \\
\hline 10. فقـرة التقريـر عـن المتطلبــات الإلزاميــة & \\
\hline 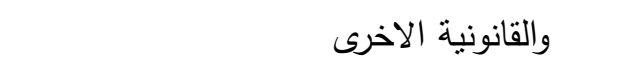 & \\
\hline 11. اسم شريك المراجعة & \\
\hline 12. توقيع مراقب الحسابات & \\
\hline 13. عنوان مراقب الحسابات & \\
\hline 14. ت تاريخ تقرير مراقب الحسابات & \\
\hline
\end{tabular}

